Review

\title{
Ionic Substitutions in Non-Apatitic Calcium Phosphates
}

\author{
Aleksandra Laskus and Joanna Kolmas * \\ Department of Inorganic and Analytical Chemistry, Faculty of Pharmacy with Laboratory Medicine Division, \\ Medical University of Warsaw, ul. Banacha 1, 02-097 Warsaw, Poland; aleksandralaskus@gmail.com \\ * Correspondence: joanna.kolmas@wum.edu.pl; Tel.: +48-225-720-784
}

Received: 9 November 2017; Accepted: 24 November 2017; Published: 27 November 2017

\begin{abstract}
Calcium phosphate materials (CaPs) are similar to inorganic part of human mineralized tissues (i.e., bone, enamel, and dentin). Owing to their high biocompatibility, CaPs, mainly hydroxyapatite (HA), have been investigated for their use in various medical applications. One of the most widely used ways to improve the biological and physicochemical properties of HA is ionic substitution with trace ions. Recent developments in bioceramics have already demonstrated that introducing foreign ions is also possible in other CaPs, such as tricalcium phosphates (amorphous as well as $\alpha$ and $\beta$ crystalline forms) and brushite. The purpose of this paper is to review recent achievements in the field of non-apatitic CaPs substituted with various ions. Particular attention will be focused on tricalcium phosphates (TCP) and "additives" such as magnesium, zinc, strontium, and silicate ions, all of which have been widely investigated thanks to their important biological role. This review also highlights some of the potential biomedical applications of non-apatitic substituted CaPs.
\end{abstract}

Keywords: calcium phosphates; ionic substitution; brushite; $\alpha \mathrm{TCP} ; \beta \mathrm{TCP}$; bioceramics

\section{Introduction}

Calcium phosphates (CaPs) are commonly used biomaterials in various medical fields, i.e., mineralized tissue surgery, implantology, orthopaedics, and stomatology. Due to their special properties, such as biocompatibility, bioactivity, nontoxicity, and osteoconductivity, they play a crucial role as bone grafts, bone fillers, and coating materials [1,2]. Most commonly, they are applied in a form of porous granules, scaffolds, or hydraulic, ready-to-use, mouldable cements. What is more, they may serve as local drug delivery systems to introduce medicines directly into the mineralized tissue [3-5].

CaPs can be obtained in different crystalline or amorphous phases, depending on the synthesis conditions (see Scheme 1). These materials differ in $\mathrm{Ca} / \mathrm{P}$ molar ratio and both physicochemical and biological properties, such as solubility, biodegradability, and bioactivity [1]. Moreover, they are stable in various $\mathrm{pHs:}$ for example, $\mathrm{HA}$ is chemically stable in aqueous solution in $\mathrm{pH}>8$, whereas octacalcium phosphate $(\mathrm{OCP})$ and dicalcium phosphate dihydrate (DCPD) in neutral and $\mathrm{pH}<6$, respectively. $\mathrm{HA}$ and tetracalcium phosphate (TTCP) are almost insoluble CaPs (solubility at $25^{\circ} \mathrm{C}$ is for HA and TTCP 0.0003 and $0.0007 \mathrm{~g} / \mathrm{dm}^{3}$ ). Regarding the easily soluble materials, amorphous calcium phosphate, monocalcium phosphate monohydrate and anhydrous (ACP, MCPM, and MCPA, respectively) should be mentioned [1]. 


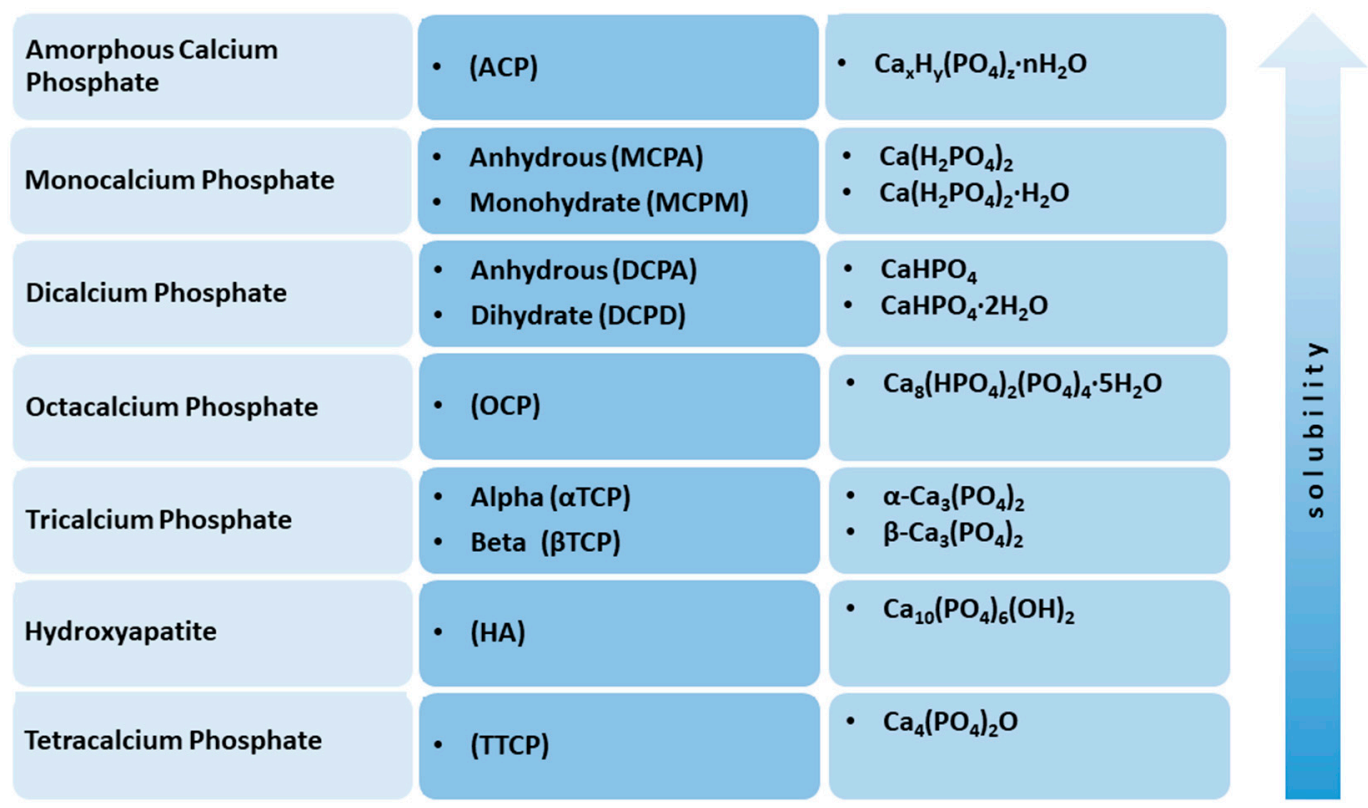

Scheme 1. Calcium phosphates of biomedical interest.

Among all CaPs, hydroxyapatite (HA) with the formula $\mathrm{Ca}_{10}\left(\mathrm{PO}_{4}\right)_{6}(\mathrm{OH})_{2}$ is the most thoroughly studied material. Thanks to its similarity to the biological apatite, the main constituent of the inorganic part of human mineralized tissues, HA is an attractive material used alone as a bioceramic or as a component of hybrid composites for biomedical engineering [6-8]. It is thoroughly documented that the chemical and biological properties of HA may be improved by the incorporation of foreign ions into its crystal structure $[9,10]$. In order to provide a few examples, the introduction of $\mathrm{Mn}^{2+}$ favours the activity and proliferation of osteoblasts and has a positive impact on the osteointegration process [11]. Fe ions improve the response of osteoblasts [9,11]. In turn, doping CaPs with selenium may give the material an anticancer potential $[9,12]$. Moreover, the slight replacement of $\mathrm{Ca}^{2+}$ with $\mathrm{Ag}^{+}$cations in the HA structure results in gaining additional antibacterial properties by the material $[9,13]$.

Recently, it turned out that other calcium phosphates, i.e., tricalcium phosphates (TCPs) and dicalcium phosphate dihydrate (DCPD), also possess a natural ability to exchange ions within their crystal lattice. Due to the fact that these CaPs are more soluble than HA [1], it gives an opportunity to create a more resorbable material, releasing therapeutic agents with favourable kinetics.

Several reviews with different approaches have been published on the topic of substituted calcium phosphates. Some of them focused on various ionic substitution in HA [9], antibacterial ions introduced into the HA crystal lattice [14], biological activity of substituted HA [15], or ion-substituted calcium phosphate coatings [16].

In turn, the aim of this work is to review the attempts made so far in the field of ionic substitutions in non-apatitic CaPs and to summarize their effects. To begin with, the biological role of the most relevant ionic substitution, followed by a short presentation of the main, non-apatitic CaPs used in biomedical applications will be presented. The final section will report the recent achievements in ionic modification of non-apatitic CaPs.

\section{The Most Relevant Ionic Substitution within the CaPs Crystal Structure}

Comprehensive studies on the composition of bone and dental tissues have led to the conclusion that biological apatite is not a pure, stoichiometric HA, but is instead, substituted by different ions, including $\mathrm{CO}_{3}{ }^{2-}, \mathrm{HPO}_{4}{ }^{2-}, \mathrm{SiO}_{4}{ }^{2-}, \mathrm{Mg}^{2+}, \mathrm{K}^{+}, \mathrm{Na}^{+}, \mathrm{Zn}^{2+}, \mathrm{Mn}^{2+}, \mathrm{F}^{-}$, or $\mathrm{Cl}^{-}[1,17]$. The quantitative and qualitative content of these "impurities" varies according to the age and condition of the tissue. However, it should be concluded that all of them play a crucial role in mineralized tissue 
metabolism [17]. Therefore, recent developments in ionic substitutions in synthetic CaP materials have mainly considered these ions that naturally occur in biological apatites. In the following sections, the most ubiquitously introduced ions will be presented.

\subsection{Magnesium $\left(\mathrm{Mg}^{2+}\right)$}

Magnesium is the fourth most abundant element in the human body. Significant amount of this element is present in bone, dentin, and enamel. As much as $60 \%$ of the body's total Mg is deposited in bone, which acts as a natural reservoir for the metal. Skeletal magnesium is located either on the surface of hydroxyapatite or in the hydrated layer around the crystal $[13,18,19]$. Magnesium contributes to the maintenance of homeostasis in mineralized tissues. An appropriate level of the metal is vital for preventing osteoporosis and other bone tissue impairments. The element's influence on mineralized tissue is both direct and indirect [19]. When it comes to the direct influence, magnesium has a significant impact on bone crystal structure and skeletal cell activity. Magnesium deficiency leads immediately to hypomagnesaemia, which is compensated through the mobilization of bone deposits [20]. This, in turn, leads to the alteration of the biological apatite structure and, as a result, a decrease in mechanical strength. Both in vitro and in vivo studies have confirmed the element's influence on bone cell activity. Magnesium stimulates osteoblast activity [21]. On the other hand, metal deficiency promotes low-grade inflammation and, as a consequence, an increase in osteoclast activity, which contributes to bone mass loss [19-21]. Among its indirect effects, magnesium has an impact on the secretion of parathyroid hormone $(\mathrm{PTH})$ and thereby a secretion of $1.25(\mathrm{OH})_{2}$ vitamin D. Experimental evidence show that the metal shortages lower the concentration of both PTH and vitamin D in serum, thereby leading to hypocalcaemia $[19,20]$.

\section{2. $\operatorname{Zinc}\left(\mathrm{Zn}^{2+}\right)$}

Zinc is the second most abundant trace metal in the human body. Approximately $86 \%$ of the total amount of this element is localized in skeletal muscles and bone tissue. The highest proportion of $\mathrm{Zn}^{2+}$ ions within the bones is localized in the osteoid and non-mineralized matrix [13,22]. Zinc acts as a cofactor for numerous enzymes and, due to this, is involved in DNA and RNA replication, protein synthesis, and bone metabolism. The element promotes both differentiation and proliferation of osteoblasts [2]. The metal's stimulating effect on osteoblastic differentiation has been partially attributed to its ability to augment the expression of runt-related transcription factor 2, which is a key transcription factor in osteoblastogenesis. In vitro studies showed that zinc also stimulates the osteoblastic production of growth factors, i.e., insulin-like growth factor (IGF-I) and transforming growth factor (TGF- $\beta$ ), both of which promote bone formation [22,23]. Experimental evidence show that zinc exhibits a stimulating effect on alkaline phosphatase (ALP), which promotes bone mineralization through the dephosphorylation of organic pyrophosphates. Simultaneously, $\mathrm{Zn}^{2+}$ ions suppress osteoclastic activity. In vitro studies revealed that zinc inhibits osteoclastic resorption mediated by PTH and proinflammatory cytokines [22]. Studies in vivo confirmed zinc's specific impact on bone cell activity and its contribution to the normal development of the skeletal system. Experiments conducted with chicks [24] and rats [25] showed that Zn supplementation increases the strength parameters of long bones, decrease extracellular bone resorption markers, and augments the level of bone formation indicators.

\subsection{Strontium $\left(\mathrm{Sr}^{2+}\right)$}

Strontium is a trace element present in significant amounts in calcified tissues [13,26]. This particularly concerns the mineral phase of bone, which is characterized by high metabolic turnover. A new developing bone is likely to contain higher concentrations of Sr than a mature one [26]. Low doses of strontium contribute to proper bone formation, while higher amounts are believed to cause osteomalacia [26,27]. It is noteworthy that strontium ranelate is one of the drugs administered to treat postmenopausal osteoporosis. It reduces significantly the risk of vertebral and non-vertebral fractures. Strontium ranelate exhibits a specific, 
dualistic influence on mineralized tissues. On the one hand, it stimulates bone formation, while on the other, it decreases its resorption. Studies in vitro showed that this particular dual-mode action of the element is caused by its stimulating effect on osteoblastic differentiation and simultaneous inhibition of osteoclastic activity [28]. What is more, experiments conducted on osteoarthritic, subchondral bone osteoblasts revealed that strontium ranelate decreases the expression of key factors affecting bone resorption [29]. An interesting in vivo study with a zebrafish as an animal model was also designed. The outcomes of the experiment demonstrated an increase in vertebral mineralization when compared with the control with lower strontium concentrations. Higher doses of strontium caused inhibited mineral deposition in dose-dependent order [30]. All of the facts mentioned above make strontium ranelate one of the drugs that is still administered as a treatment of osteoporosis [31].

\subsection{Silicon $\left(\mathrm{SiO}_{3}{ }^{2-}, \mathrm{SiO}_{4}{ }^{2-}\right)$}

Silicon is the third most abundant trace element in the human body [32]. It significantly affects bone metabolism and contributes to proper mineralized tissue formation. A particularly high concentration of silicon can be found in metabolically active skeletal cells. A relatively high level of the element is found in the mitochondria of these cells. A pioneer in investigating silicon's influence on bone metabolism was Carlisle [33-36]. In vitro and in vivo studies conducted by Carlisle [33-36] proved that silicon is localized in active bone growth areas. This, in turn, suggested that Si plays a physiological role in the mineralization process. What is more, the scientists observed that silicon deficiency contributes to problems with normal growth and skeletal development abnormalities $[32,33,37]$. Over the years, Carlisle's observations have been confirmed. Dietary silicon can be absorbed in the form of orthosilicic acid $\left(\mathrm{H}_{4} \mathrm{SiO}_{4}\right)$. Studies $[32,37,38]$ have investigated the influence of this acid on bone metabolism. Experiments conducted in osteoblastic cell line MG-63 showed that orthosilicic acid promotes the synthesis of collagen type 1 and augments osteoblastic differentiation markers, i.e., alkaline phosphatase and osteocalcin levels [37]. Silicon does not affect the expression of the collagen type 1 gene, but it does stimulate the prolyl hydrolase involved in collagen synthesis [32]. In vivo studies also confirmed a stimulating effect of the element on collagen type 1, including randomized trials conducted in osteopenic women [38]. Overall, an adequate $\mathrm{Si}$ level is crucial for maintaining higher bone mineral density (BMD). It contributes to bone mineralization and accelerates the calcification rate [39-42].

\section{Non-Apatitic Calcium Phosphates}

Unlike biological apatites, non-apatitic calcium phosphates are not present in normal mineralized tissues. They frequently occur in pathological calcifications such as dental calculi, urinary stones or heart valve calcifications [43]. Non-apatitic CaPs, except crystalline TCP and TTCP, can be easily synthesized using standard wet methods, by adjusting the $\mathrm{Ca} / \mathrm{P}$ ratio, the $\mathrm{pH}$ of the solution and the temperature beforehand [44]. As was mentioned above, the various types of non-apatitic CaPs differ in their solubility, which decreases as follows: $\mathrm{ACP}<\mathrm{MCPM}<\mathrm{MCPA}<\mathrm{DCPD}<\mathrm{OCP}<\alpha \mathrm{TCP}<\mathrm{TTCP}<\beta \mathrm{TCP}$ [45]. In general, non-apatitic $\mathrm{CaPs}$ are more soluble and less stable than hydroxyapatite, which allows them transform easily into apatites and substituted apatites or other calcium phosphates under physiological conditions through the dissolution-precipitation process [44].

\subsection{Amorphous Calcium Phosphate (ACP)}

Amorphous calcium phosphate (ACP) is a hydrated, thermodynamically unstable, transient phase that commonly precipitates during the formation of more stable CaPs in aqueous systems. The structure of ACP is still being discussed in the literature [46]. Briefly, it is proposed that the main structural unit has a nearly spherical cluster measuring $9.5 \AA$ in diameter with the basic composition of $\mathrm{Ca} 9\left(\mathrm{PO}_{4}\right)_{6}$ [47]. Moreover, the clusters are interspersed with water molecules (in various contents) [48]. The presence of acidic phosphates in the ACP structure is also under investigation. ACP can be obtained by wet precipitation in aqueous medium at low temperature (the wet method) and by using high energy processing and high temperature (the dry method) $[48,49]$. As the wet method is more 
ubiquitously applied, only this route will be briefly outlined below. Wet synthesis may be undertaken either in aqueous medium or a water-alcohol solution. Usually, it consists of two steps: rapid mixing of the reagents and precipitate filtration. Low or room temperature, high supersaturation, and a $\mathrm{pH}$ close to 10 are required. The reaction consists of a double decomposition of calcium (e.g., $\mathrm{Ca}\left(\mathrm{NO}_{3}\right)_{2} \cdot 4 \mathrm{H}_{2} \mathrm{O}$ ) and phosphate (e.g., $\left.\left(\mathrm{NH}_{4}\right)_{2} \mathrm{HPO}_{4}\right)$ salt in the aqueous or water-alcohol medium [48,49]. After rapid mixing and precipitate filtration, the powder is lyophilized. The prepared ACP is stored in a freezer in order to prevent conversion or phase transformation. The ACP's structure and chemical composition depends on the $\mathrm{pH}$ and composition of the mother solution. Hence, the $\mathrm{Ca} / \mathrm{P}$ ratio of the synthesized $\mathrm{ACP}$ can range from 1 to 2 , or even higher. Having said this, the most commonly known $\mathrm{Ca} / \mathrm{P}$ ratios are 1.5 and 1.33 [48]. The $\mathrm{P} \beta$ diffractogram of ACP is typical for amorphous materials: it only presents a very broad line with no narrow reflections [47].

Due to the significant chemical and structural similarities to calcified tissues, as well as its excellent biocompatibility and bioresorbability, ACP is commonly used as a component of calcium phosphates cements (CPCs) in surgery or dentistry. Owing to the fact that it can easily transform into biological apatites, it could also be a promising material for the artificial bone grafts engineering. According to the literature, several mechanisms of $\mathrm{ACP}$ transformation into crystalline apatite are proposed, depending on $\mathrm{pH}$ or the presence of other ions $[47,48]$. In several cases, the intermediate phase is OCP [48]. It should be also noted, that ACP occurs naturally in soft tissue pathological calcifications, i.e., heart valve calcifications $[43,49,50]$.

\subsection{Dicalcium Phosphate Dihydrate (DCPD)}

Dicalcium phosphate dihydrate, also known as brushite or calcium hydrogen phosphate dihydrate, is a crystalline calcium phosphate that can be described using the formula $\mathrm{CaHPO}_{4} \cdot 2 \mathrm{H}_{2} \mathrm{O}$. It crystallizes in the monoclinic Ia space group (see Figure 1). The DCPD crystals consist of CaP chains arranged parallel to each other, with water molecules situated between the chains [47].

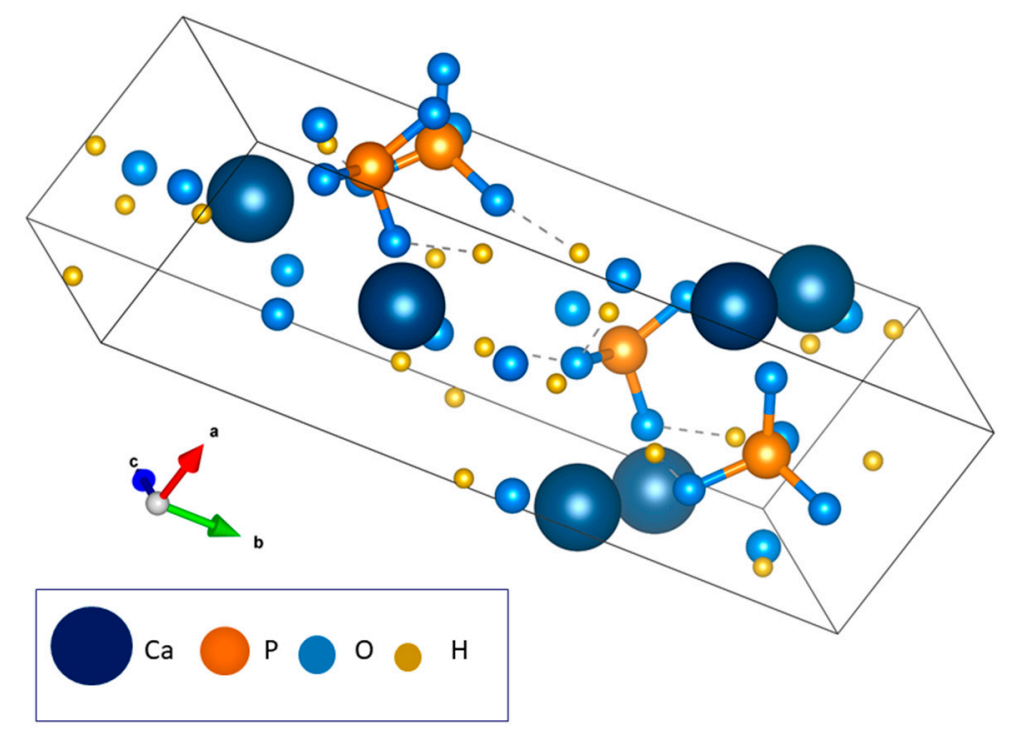

Figure 1. Crystalline structure of dicalcium phosphate dihydrate (DCPD).

DCPD is naturally present in dental calculi, urinary stones and precipitations involved in chondrocalcinosis [43]. In laboratory terms, it crystallizes easily from aqueous solutions and is stable in acidic environments, namely the $\mathrm{pH}$ between 4 and 6 . Most commonly, it is obtained by mixing calcium chloride $\mathrm{CaCl}_{2}$ with $\mathrm{NaH}_{2} \mathrm{PO}_{4}$ or $\mathrm{NH}_{4} \mathrm{H}_{2} \mathrm{PO}_{4}$ in a water solution. The synthesis is carried out according to the following chemical reaction [51]:

$$
\mathrm{Na}_{2} \mathrm{HPO}_{4}+\mathrm{CaCl}_{2}+2 \mathrm{H}_{2} \mathrm{O} \rightarrow \mathrm{CaHPO}_{4} \cdot 2 \mathrm{H}_{2} \mathrm{O}+2 \mathrm{NaCl}
$$


Apart from the starting materials listed above, other calcium and phosphate sources can also be employed. Among them, calcium hydroxide $\left(\mathrm{Ca}(\mathrm{OH})_{2}\right)$, calcium nitrate $\left(\mathrm{Ca}(\mathrm{NO})_{3}\right)$ or calcium acetate $\left(\mathrm{CH}_{3} \mathrm{COOH}\right)_{2} \mathrm{Ca}$ and phosphoric acid $\left(\mathrm{H}_{3} \mathrm{PO}_{4}\right)$ should be mentioned [49,52-54]. As demonstrated above, the reagents are mixed in an equimolar ratio. The proper $\mathrm{pH}$ value is usually maintained by the addition of $\mathrm{HNO}_{3}, \mathrm{HCl}, \mathrm{H}_{3} \mathrm{PO}_{4}$, and $\mathrm{KOH}$ or $\mathrm{NH}_{4} \mathrm{OH}$. The literature provides data showing that brushite forms at the $\mathrm{pH}$ of 5 and the temperature of $37^{\circ} \mathrm{C}$. In order to synthesize DCPD at the $\mathrm{pH}$ of 6, the temperature should be lowered to $25^{\circ} \mathrm{C}$ [55].

Brushite can be also obtained by mixing two different calcium phosphate powders in water [54]. The starting materials are $\beta \mathrm{TCP}$ and monocalcium phosphate hydrate $\left(\mathrm{Ca}\left(\mathrm{H}_{2} \mathrm{PO}_{4}\right)_{2} \cdot \mathrm{H}_{2} \mathrm{O}\right)$. Sodium pyrophosphate $\left(\mathrm{Na}_{2} \mathrm{H}_{2} \mathrm{PO}_{4}\right)$ is added to the mixture as a setting regulator. The synthesis may be conducted in a sulphuric acid solution or in inorganic (silica) and organic (collagen) gels [55].

It should be noted that brushite is a metastable material. It transforms easily into the anhydrous form monetite $\left(\mathrm{CaHPO}_{4}\right)$. Dehydration begins already in atmospheric conditions [51]. Under the physiological $\mathrm{pH}$ ranging from 7 to 7.5, DCPD transforms into HA. An essential aspect is that it resorbs much faster than apatite and, due to this, is widely applied in surgery as a CPC component. Moreover, in dentistry it is used as an anti-plaque factor in toothpastes $[43,55,56]$.

\subsection{Tricalcium Phosphate (TCP)}

Tricalcium phosphate, which can be described with the general formula $\mathrm{Ca}_{3}\left(\mathrm{PO}_{4}\right)_{2}$, exists in two allotropic forms, i.e., $\alpha$ and $\beta \mathrm{TCP}$, both of which are of great importance from the biological point of view. Schematic models of the crystal structures of these materials are presented in Figure 2. $\alpha \mathrm{TCP}$ crystallizes in the monoclinic space group $\mathrm{P} 2{ }_{1} / \mathrm{a}$, whereas $\beta \mathrm{TCP}$ possesses a rhombohedral structure [47].
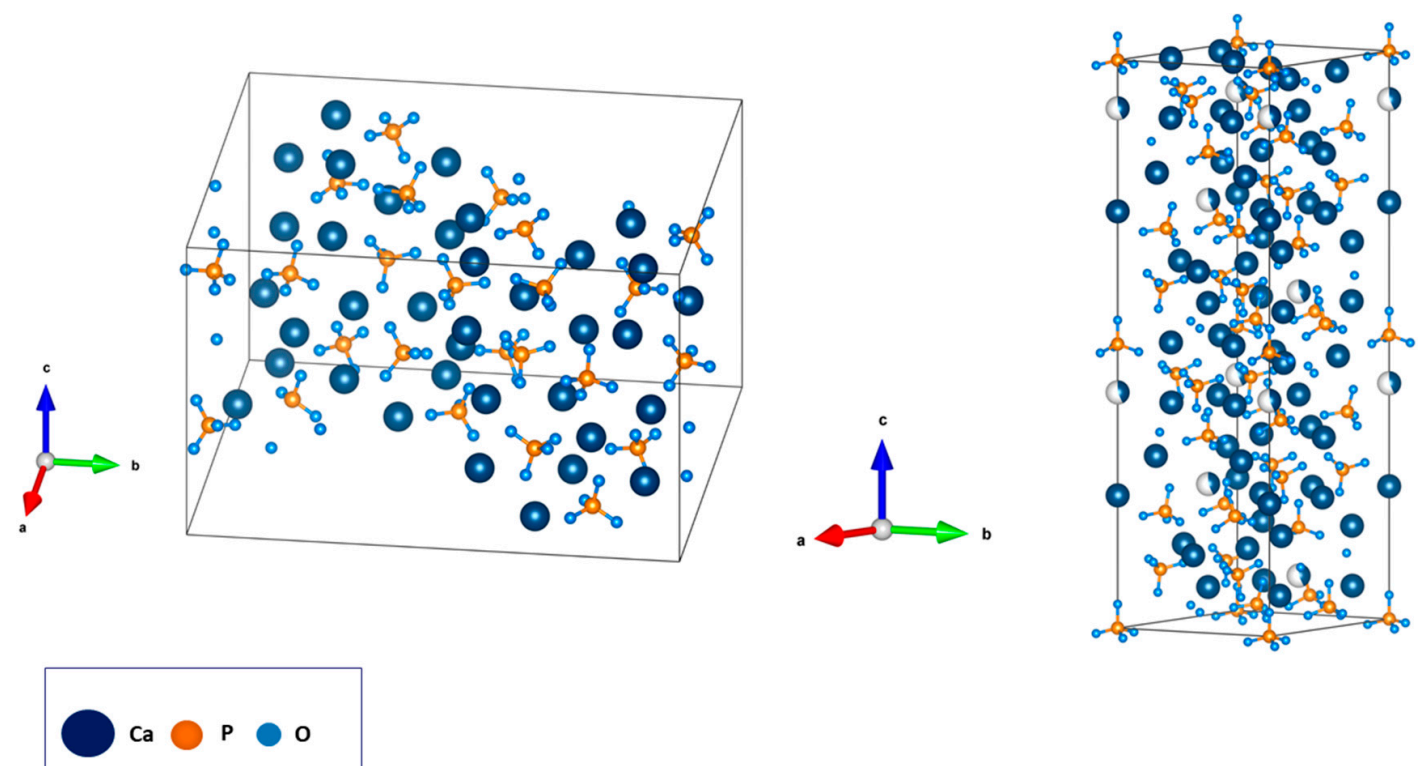

Figure 2. The crystalline structures of tricalcium phosphate (TCP): $\alpha$ form (left) and $\beta$ form (right).

As the hydroxyapatite earned its immense popularity in biomedicine due to its great similarity to biological apatite, TCP is still gaining interest thanks to its relatively high solubility. Both HA and TCP form a strong bond with the mineralized tissue and favour bone formation. Due to the poor resorbability of HA, both CaPs are often mixed together in different ratios in order to increase the bioreactivity of the material [57-59].

$\alpha \mathrm{TCP}$ is a high temperature allotropic form, which comes into being during the heat treatment of $\beta$ TCP above $1125^{\circ} \mathrm{C}$ [60]. The synthesis of $\alpha \mathrm{Ca}_{3}\left(\mathrm{PO}_{4}\right)_{2}$ brings one major problem, which is the metastability of the obtained material under the room temperature. Its thermal stability ranges from 
1430 to $1470{ }^{\circ} \mathrm{C}$. Thus, synthesizing $\alpha \mathrm{TCP}$ at a high temperature requires immediate cooling to stabilize the structure after the previous heat treatment $[60,61] . \alpha \mathrm{TCP}$ is highly soluble and together with a liquid phase forms a hard and stable material that is used in bone cements. It should be also noted that $\alpha \mathrm{TCP}$ transforms into CDHA in water medium according the following reaction [60]:

$$
3 \mathrm{Ca}_{3}\left(\mathrm{PO}_{4}\right)_{2}+\mathrm{H}_{2} \mathrm{O} \rightarrow \mathrm{Ca} 9\left(\mathrm{PO}_{4}\right)_{5}\left(\mathrm{HPO}_{4}\right) \mathrm{OH}
$$

$\alpha \mathrm{TCP}$ can be obtained via different methods, i.e., precursor's thermal transformation, solid-state precursors' reaction and self-propagating, high-temperature or combustion synthesis [61]. When it comes to thermal transformation, the decomposition may consider CDHA, ACP or $\beta$ TCP (see Equations (1)-(3)):

$$
\begin{gathered}
\mathrm{Ca} 9\left(\mathrm{HPO}_{4}\right)\left(\mathrm{PO}_{4}\right)_{5}(\mathrm{OH})_{(\mathrm{s})} \rightarrow 3 \alpha \mathrm{Ca}_{3}\left(\mathrm{PO}_{4}\right)_{2(\mathrm{~s})}+\mathrm{H}_{2} \mathrm{O}_{(\mathrm{g})}\left(\mathrm{T} \geq 1150{ }^{\circ} \mathrm{C}\right) \\
\mathrm{Ca}_{9}\left(\mathrm{PO}_{4}\right)_{6} \cdot \mathrm{nH}_{2} \mathrm{O}_{(\mathrm{s})} \rightarrow \alpha \mathrm{Ca}_{3}\left(\mathrm{PO}_{4}\right)_{(\mathrm{s})}+\mathrm{nH}_{2} \mathrm{O}_{(\mathrm{g})}\left(600{ }^{\circ} \mathrm{C} \leq \mathrm{T} \leq 800{ }^{\circ} \mathrm{C}\right) \\
\beta \mathrm{Ca}_{3}\left(\mathrm{PO}_{4}\right)_{(\mathrm{s})} \rightarrow \alpha \mathrm{Ca}_{3}\left(\mathrm{PO}_{4}\right)_{(\mathrm{s})}\left(1125^{\circ} \mathrm{C} \leq \mathrm{T} \leq 1430{ }^{\circ} \mathrm{C}\right.
\end{gathered}
$$

Both the decomposition of CDHA (Equation (1)) and ACP (Equation (2)) are commonly applied [57]. Starting materials are usually synthesized using the wet precipitation method. Nonetheless, high temperature, $\beta \mathrm{TCP}$ to $\alpha \mathrm{TCP}$ crystalline phase transition is the most direct and the simplest way to obtain $\alpha \mathrm{Ca}_{3}\left(\mathrm{PO}_{4}\right)$ [62-66].

Considering obtaining $\alpha \mathrm{TCP}$ via solid-state reaction, the most commonly applied synthesis routes are listed below [67-71].

$$
\begin{gathered}
\mathrm{CaCO}_{3(\mathrm{~s})}+2 \mathrm{CaHPO}_{4(\mathrm{~s})} \rightarrow \alpha \mathrm{Ca}_{3}\left(\mathrm{PO}_{4}\right)_{2(\mathrm{~s})}+\mathrm{CO}_{2(\mathrm{~g})}+\mathrm{H}_{2} \mathrm{O}(\mathrm{g}) \\
3 \mathrm{CaCO}_{3(\mathrm{~s})}+2 \mathrm{NH}_{4} \mathrm{H}_{2} \mathrm{PO}_{4(\mathrm{~s})} \rightarrow \alpha \mathrm{Ca}_{3}\left(\mathrm{PO}_{4}\right)_{2(\mathrm{~s})}+3 \mathrm{CO}_{2(\mathrm{~g})}+3 \mathrm{H}_{2} \mathrm{O}_{(\mathrm{g})}+2 \mathrm{NH}_{3(\mathrm{~g})} \\
\mathrm{CaCO}_{3(\mathrm{~s})}+\mathrm{Ca}_{2} \mathrm{P}_{2} \mathrm{O}_{7(\mathrm{~s})} \rightarrow \alpha \mathrm{Ca}_{3}\left(\mathrm{PO}_{4}\right)_{2(\mathrm{~s})}+\mathrm{CO}_{2(\mathrm{~g})} \\
\mathrm{Ca}_{10}\left(\mathrm{PO}_{4}\right)_{6}(\mathrm{OH})_{2(\mathrm{~s})}+2 \mathrm{CaHPO}_{4(\mathrm{~s})} \rightarrow 4 \alpha \mathrm{Ca}_{3}\left(\mathrm{PO}_{4}\right)_{2(\mathrm{~s})}+2 \mathrm{H}_{2} \mathrm{O}_{(\mathrm{g})}
\end{gathered}
$$

In general, solid-state reaction scheme consists of a few stable steps: milling the powder mixture, putting the ground mixture under pressure and finally heating the powder above the transformation temperature. The first two stages serve to reduce the particles size, promote proper homogenization and increase the contact area. When it comes to the heat treatment parameters, the recommended temperature ranges from 1250 to $1500{ }^{\circ} \mathrm{C}$. In turn, the sintering time may vary from 2 to $48 \mathrm{~h}$. To avoid the reversion of the crystal phase, quenching should be employed immediately [61].

Less common ways of obtaining $\alpha \mathrm{TCP}$ are self-propagating, high-temperature, and combustion synthesis [72-75]. Briefly, they consist in preparing a mixture of $\mathrm{Ca}$ and $\mathrm{P}$ sources in a proper ratio, either as a solid pellet or solution, and the heat treatment. In case of the self-propagating, high temperature method, the heat is applied from an external source, while in case of the self-combustion route, the reagent solution contains an organic, inflammable fuel (e.g., urea) that acts as a catalyst for the self-combustion of the mixture [72-75].

Recently, some novel approaches to $\beta$ TCP synthesis have been made [51,76-78]. Herein, they will be briefly presented, together with more conventional and ubiquitously employed methods. In general, $\beta T C P$ synthesis methods include:

- Thermal transformation of the precursor;

- Solid-state synthesis;

- Wet chemical precipitation;

- Sol-gel technique;

- Self-combustion method. 
The most conventional methods from the above are thermal transformation of the precursor, solid-state synthesis and wet chemical precipitation. Most frequently, thermal transformation of the precursor consists in calcination of previously precipitated CDHA at the temperature above $800{ }^{\circ} \mathrm{C}[55,77]$. When it comes to solid-state synthesis, possible reactions schemes that can be employed are similar to those presented for $\alpha \mathrm{TCP}$. The only differences concern the heat treatment parameters, which should be maintained at the level preventing $\beta \mathrm{TCP}$ to $\alpha \mathrm{TCP}$ phase transition. In turn, wet chemical precipitation consists in precipitating $\mathrm{CaP}$ at a $\mathrm{Ca} / \mathrm{P}$ molar ratio of $\approx 1.5$ followed by the product's calcination.

Another interesting method is a sol-gel technique [77]. In this case, the precipitation is carried out in very acidic conditions. The proper $\mathrm{pH}$ value is usually achieved by the addition of citric acid or concentrated nitric acid, and varies from 2 to 3 . The sol-gel transformation is caused by vigorous mixing of $\mathrm{Ca}$ and $\mathrm{P}$ sources in a liquid medium during the simultaneous heating up to 80 to $90^{\circ} \mathrm{C}[76,77]$.

The self-combustion method has already been described. An alternative to this method is microwave self-combustion synthesis [78].

An essential property of TCP is that, similarly to hydroxyapatite, it forms a strong bond with mineralized tissue and favours bone formation. Due to its relatively high solubility, it is commonly applied as a component of calcium phosphate cements and other bone substitutes [56,57,61].

\section{Ionic Substitutions in Non-Apatitic Calcium Phosphates}

\subsection{Substituted Amorphous Calcium Phosphate (ACP)}

As mentioned above, unsubstituted ACP cannot be formed at the physiological $\mathrm{pH}$ level. It usually forms at the alkaline $\mathrm{pH}$ of about 10. Introducing some specific ions, i.e., $\mathrm{Mg}^{2+}, \mathrm{Sn}^{2+}, \mathrm{Al}^{3+}, \mathrm{P}_{2} \mathrm{O}_{7}{ }^{4-}$, and $\mathrm{CO}_{3}{ }^{2-}$, stabilizes the ACP and inhibits its transformation into HA [48]. Sometimes, such a modification can also promote hydrolysis to brushite instead of apatite. Lee and Kumta [51] decided to modify ACP with $\mathrm{Mg}^{2+}$ ions mainly because of their excellent biocompatibility. They used a precipitation method, with $\mathrm{MgCl}_{2}$ as a source of magnesium. The concentrations of $\mathrm{Ca}$ and $\mathrm{P}$ in the two conducted experiments corresponded to the composition of $\mathrm{HA}(\mathrm{Ca} / \mathrm{P}=1.67)$ and TCP $(\mathrm{Ca} / \mathrm{P}=1.5)$. The magnesium content was maintained at the level of $30 \mathrm{~mol} \%$ and $20 \mathrm{~mol} \%$ for the HA and TCP, respectively. Physicochemical analysis was carried out. The results revealed that $\mathrm{Mg}$ ions act as a phase stabilizer. During the heat treatment of ACP, $\alpha \mathrm{TCP}$ is known to form at $600^{\circ} \mathrm{C}$. The addition of $\mathrm{Mg}^{2+}$ stabilized $\mathrm{MgTCP}$ at this temperature and retarded its transformation [51].

The in vitro biological activity of Mg-substituted ACP, amorphous magnesium phosphate (AMP) and pure HA was tested on MC3T3-E1 preosteoblasts [79]. In general, the results for amorphous materials (Mg-substituted ACP and AMP) have demonstrated higher proliferation and differentiation rate as well as higher mineralization of preosteoblast cells than HA samples.

The effect of silicon doping on the transformation of ACP to $\alpha \mathrm{TCP}$ has been investigated by Dong et al. [80]. During the synthesis of HA with high silicon concentration, the amorphous phase enriched with Si was easily formed and then transformed to $\alpha \mathrm{SiTCP}$ at lower temperatures than SiHA.

Kato et al. [81] have prepared potassium-substituted ACP for potential application in dentin hypersensitivity treatment. It has been shown that potassium release from amorphous material is significantly larger than from potassium-substituted hydroxyapatite. ACP enriched in silver ions was prepared via chemical precipitation method by Yu et al. [82]. The obtained AgACP material, together with slightly acidic compounds were then used to produce calcium phosphate cements (CPCs). The sufficient silver release and high cytotoxic effect toward Escherichia coli were demonstrated only in the samples prepared without heat treatment.

\subsection{Substituted Dicalcium Phosphate Dihydrate (DCPD)}

Modifying brushite with foreign ions is also an object of scientific interest. DCPD is a material commonly used as a component of CPCs, as it transforms easily to HA under physiological conditions. The most ubiquitously applied ionic substitution in case of brushite is magnesium, mainly due to the 
potential enhancement of the bioactivity of such a modified material [51,83-86]. Some studies also deal with the introduction of silicon [87], strontium [88,89], cuprum [90], zinc [91], and iron [92]. Recently, a study concerning the introduction of nickel has been also conducted [93]. Alkhraisat and Cabrejos-Azama focused on magnesium-modified, brushite-based CPC [83-85]. Various ways of introducing $\mathrm{Mg}^{2+}$ ions into brushite cements were investigated and reported, also.

Alkhraisat et al. [83] used TCP and magnesium-substituted TCP as substrates in this process. In their studies, the preparation of brushite cement consisted of the following few steps:

- $\quad$ Preparation of $\beta \mathrm{TCP}$ and $\beta \mathrm{MgTCP}$ powder via solid-state synthesis;

- Addition of MCPM to previously crushed and mixed powders;

- Addition of water to the composed powder;

- Mixing in mortar.

By modifying the substrate (TCP) with different amounts of $\mathrm{Mg}^{2+}$, Alkhraisat et al. [83] managed to replace $3 \%$ of the $\mathrm{Ca}^{2+}$ with $\mathrm{Mg}^{2+}$ ions in the final product. The final setting time of the CPC increased, together with its magnesium content. Moreover, the release rate of the ions was affected. The release of $\mathrm{Ca}^{2+}$ decreased as the $\mathrm{Mg}^{2+}$ concentration increased, which is a result of magnesium's inhibiting influence on the dissolution of brushite. A similar observation was made by Lee and Kumta in their work [51]. Hence, it could be stated that $\mathrm{Mg}^{2+}$ acts as a phase stabilizer of DCPD.

In turn, Correia et al. [94] studied the role of $\mathrm{Mg}^{2+}$ ions on the growth of acidic calcium phosphate crystals: OCP and DCPD. It was shown that the presence of $\mathrm{Mg}^{2+}$ could affect the morphology of the coatings obtained by electrodeposition. Magnesium inhibited the OCP and DCPD crystal growth due to surface adsorption and doping process, respectively [94].

In the study [84], the biological properties of magnesium-modified brushite cement were examined (see Figures 3 and 4). The investigation involved cell studies and animal model experiments. The evaluation of the in vitro response to the cement was conducted using the osteoblastic cell line MG-63. In turn, in vivo tests were performed using a rabbit model. Both in vitro and in vivo studies proved that there was an increased biological response in case of $\mathrm{MgCPC}$ in comparison with unmodified CPC. Specifically, cell proliferation, cell adhesion, and bone formation all increased. No manifestation of inflammation was observed [84].

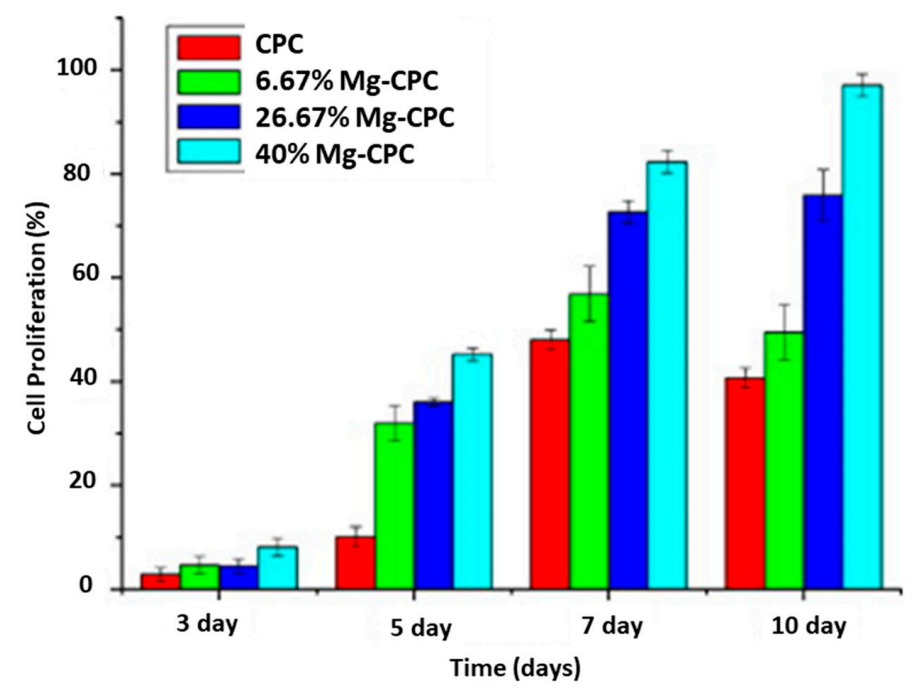

Figure 3. Cell proliferation after seeding on calcium phosphates cement (CPC) and MgCPCs (error bars represent SD). Reprinted from [84] with permission from Elsevier.

Alkhraisat et al. [88] also carried out studies concerning the impact of strontium and pyrophosphates on the physicochemical properties of brushite cement. The results showed that both $\mathrm{Sr}^{2+}$ and $\mathrm{P}_{2} \mathrm{O}_{7}{ }^{2-}$ inhibit the cement setting reaction. 


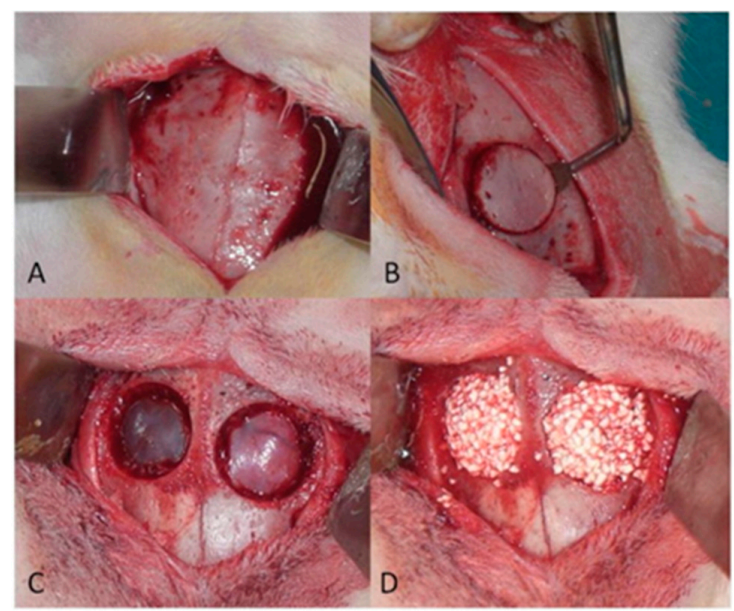

Figure 4. (A) Rabbit calvaria exposed; (B) removal of bone block; (C) bone defects exposed; (D) bone defects filled with bone substitute. Reprinted from [84] with permission from Elsevier.

Cabrejos-Azama et al. [85] used magnesium-substituted DCPD cement as a drug carrier. Vancomycin, an antibiotic commonly used against Staphylococcus aureus, which is one of the most frequent pathogens associated with mineralized tissue infections, was chosen as a model drug. The cement was loaded with the antibiotic through the adsorption from the solution or introduction into the solid phase of cement. The release profile varied together with Mg content in the TCP used as one of the reagents in the preparation of brushite cement (see Figure 5). The material prepared with $\beta \mathrm{MgTCP}$ containing $66.67 \% \mathrm{Mg}^{2+}$ released vancomycin with zero-order kinetics. Vancomycin was also used as a drug model in study [87], in which silicon was chosen as an ionic modifier. The investigated material was CPC-silica gel composite. The composite was obtained through the infiltration of the macropores of the CPC by the silica gel. The infiltration process altered both density of the material and the release mode of vancomycin. In comparison with unmodified $\mathrm{CPC}, 25 \%$ of previously introduced drug remained in the SiCPC matrix. The cytocompatibility of obtained composite was also examined. The composites with the highest silicate content performed as high cell proliferation as hydroxyapatite, which was one of the reference materials. However, biological response did not correlate with the release rate of silicon from the material, but seemed to be attributed to the phosphate release and magnesium absorption from the cell culture medium [87].

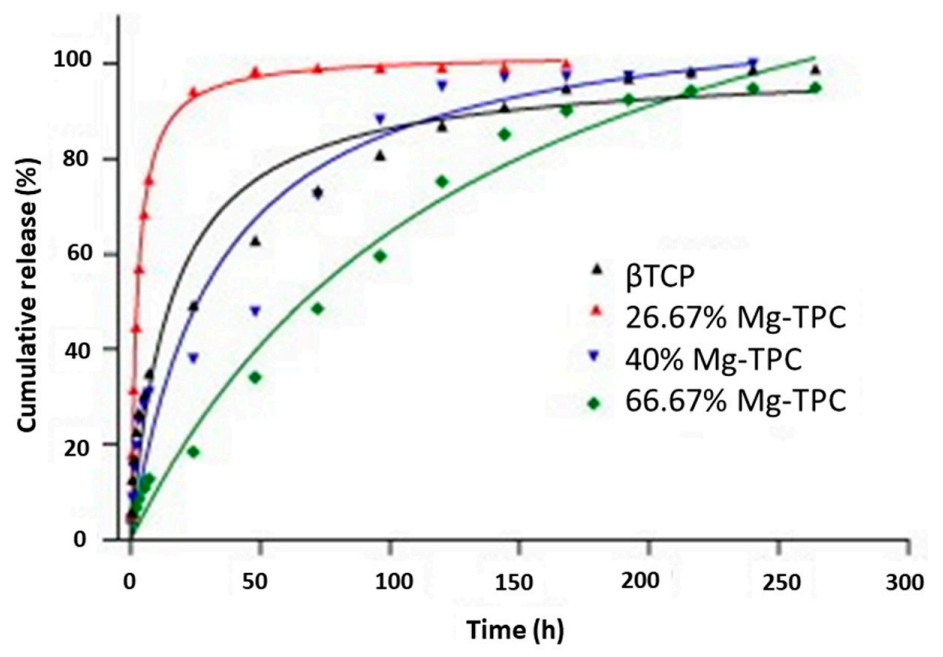

Figure 5. Release of vancomycin from different CPCs. Reprinted from [85] with permission from Elsevier. 
The available literature contains also the co-substituted DCPD cements information $[95,96]$. Torres et al. [95] focused on co-doping DCPD with the combination of $\mathrm{Mn}^{2+}$ and $\mathrm{Sr}^{2+}$. The injectable cement contained also an addition of sucrose, which improved its biological and mechanical properties. In turn, Vahabzadeh et al. [96] studied the influence of $\mathrm{Si}$ and $\mathrm{Zn}$ ions as dopants of DCPD on the physical, biological, and mechanical properties of cements. In vivo results revealed that $\mathrm{Si}$ and $\mathrm{Zn}$ addition may improve the early stage osseointegration process [96].

\subsection{TCP Substituted with Foreign Ions}

Ionic substitution in both $\alpha$ and $\beta$ TCP is currently being investigated. A solid-state reaction, as well as the heat treatment of already precipitated powders, are commonly applied to synthesize these materials [97-146]. It is worth underlining that there are two main directions in ionic modification of $\alpha$ and $\beta$ TCP. One of them is improving the properties of CaP, while the second one is stabilizing the phase. In the following paragraph the most interesting studies on this topic will be briefly discussed.

\subsection{1. $\alpha \mathrm{TCP}$ Substituted with Different Ions}

Various elements, including $\mathrm{Mg}, \mathrm{Sr}, \mathrm{Si}$, and $\mathrm{Ag}$, are being successfully introduced into $\alpha \mathrm{TCP}$ 's crystal lattice. It should be underlined that $\mathrm{Si}$ is the most widely applied and thoroughly examined dopant.

$\alpha$ SiTCP samples can be obtained using various wet and solid-state methods [98-103]. Reid et al. [98] prepared Si-substituted $\alpha \mathrm{TCP}$ using one of the most ubiquitous ways of synthesis, i.e., by sintering previously precipitated precursor, which was Si-enriched CaP. The applied temperature was $1250{ }^{\circ} \mathrm{C}$, and the single-phase samples contained $0.59-1.14 \mathrm{wt} \%$ of $\mathrm{Si}$.

As stated before, pure $\alpha \mathrm{TCP}$ is stable only in the range of 1430 to $1470{ }^{\circ} \mathrm{C}$. Thus, it is important to note that the addition of silicon favours the formation of $\alpha \mathrm{TCP}$ and helps to stabilize its structure in lower temperature [97]. The chemical reactivity of $\alpha \mathrm{SiTCP}$ was also examined by Moitsuke et al. [100]. $\alpha \mathrm{TCP}$ is known to convert easily to calcium-deficient hydroxyapatite in water solution. However, the study showed that, in comparison with pure $\alpha \mathrm{TCP}$, the reactivity of $\alpha \mathrm{SiTCP}$ was significantly lower. This could be related to the release of silicon and formation of an amorphous Si layer slowing down the dissolution-precipitation reaction.

Interesting conclusions were made by Reid et al. in their work [105]. The study considered the influence of the presence of magnesium impurities in one of the reactants on the phase composition of obtained powder. To synthesize the final material, the sol-gel technique combined with the appropriate heat treatment was applied. Surprisingly, it turned out that an Mg content of barely 250 to the chemical structure of $\alpha \mathrm{SiTCP}$ was investigated by Duncan et al. [99], who obtained high-purity $\alpha \mathrm{SiTCP}$ through a solid-state reaction in a furnace at $1300^{\circ} \mathrm{C}$. Detailed physicochemical analysis (X-ray diffraction with Rietveld analysis and solid-state nuclear magnetic resonance) allowed to confirm crystal structure and silicon incorporation. Moreover, the obtained results suggested the presence of silicate and disilicate ions that partially substituted phosphate groups in crystallographic sites. Silicon substitution into the $\alpha \mathrm{TCP}$ crystals resulted in a significant increase of $b$ axis length and the $\beta$ angle [99].

During the last few years $\alpha$ SiTCP has been also examined in vivo [101-103]. Cylindrical implants, ceramic blocks [102,103] or porous granules based on this material [101] have already been prepared and examined by conducting biological tests on rabbit and rat models. All the materials demonstrated good bioactivity and biocompatibility as well as mechanical properties [102]. What is more, the addition of Si promoted osteogenesis and again, retarded biodegradation of $\alpha$ TCP [101].

Not only silicon has been used as a ionic modifier of $\alpha$ TCP. The study [104] considered applying a hydrothermal method to obtain hydroxyapatite (as a precursor of $\alpha \mathrm{TCP}$ ) modified with $\mathrm{Cu}^{2+}$ and $\mathrm{Ag}+$. The as prepared HA powder was put under the temperature of $1200^{\circ} \mathrm{C}$ for two hours in order to examine the influence of dopants on the creation of biphasic HA/ $\alpha \mathrm{TCP}$ powder. The aim of the study was also to investigate the antimicrobial activity of the prepared material. All of the annealed powders consisted mainly of spherical particles (see Figure 6). The doping of foreign ions had slightly negative influence on the creation of biphasic material. The antimicrobial activity of both modified HA and 
biphasic powder were evaluated against Staphylococcus aureus, Escherichia coli, Pseudomonas aeruginosa, and Candida albicans - the bacterial and yeast strains responsible for common human infections.

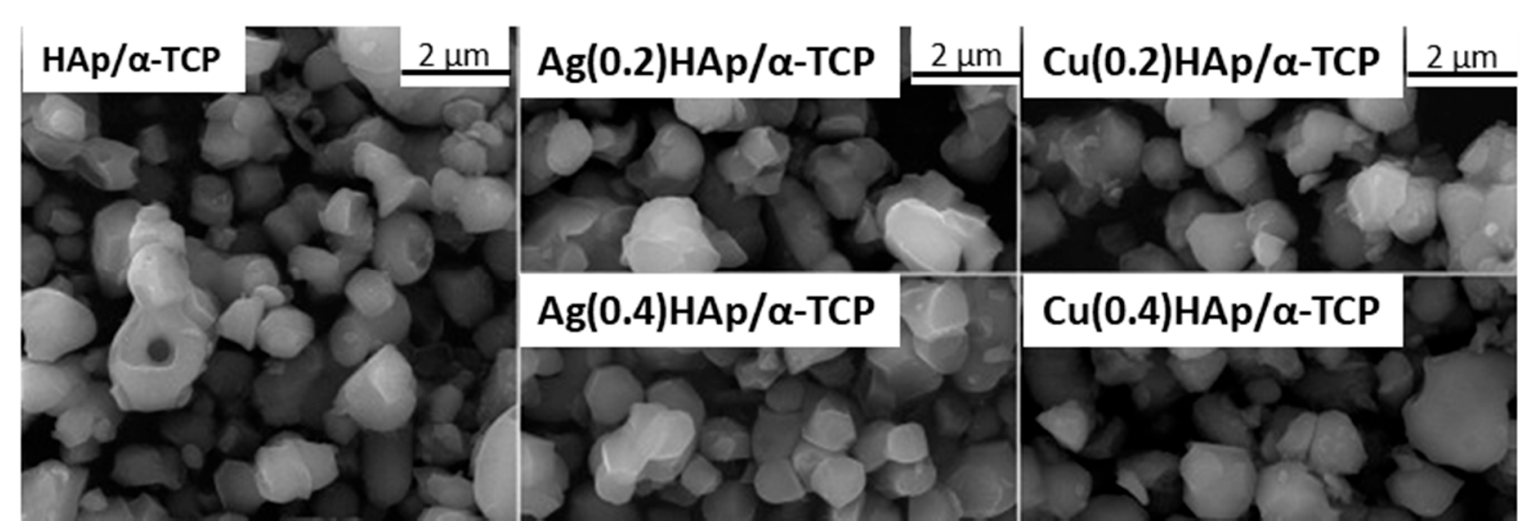

Figure 6. Field emission scanning electron microscopy (FESEM) micrographs of the powders calcified at $1200{ }^{\circ} \mathrm{C}(\mathrm{CuAg})$. Scale bar: $2 \mu \mathrm{m}$. Reprinted from [104] with permission from Elsevier.

Although the tests showed that more ions were released from the doped HA, the biphasic powder performed more homogenous and, in some cases, better antimicrobial activity than modified HA. The authors believe that this phenomenon can be explained by the adsorption of microorganisms on the surface of the $\mathrm{HA} / \alpha \mathrm{TCP}$, which put them in close contact with antimicrobial agents, i.e., $\mathrm{Ag}^{+}$and $\mathrm{Cu}^{2+}$, preventing further expansion [104].

In turn, Tong et al. [106] presented an unconventional approach, which examined the introduction of foreign ions into $\alpha \mathrm{TCP}$. Using a solid-state technique, they modified the $\mathrm{CaP}$ with $\mathrm{Eu}^{3+}$. The outcomes of the study suggested that, due to the self-reduction, europium could serve as a spectroscopic probe for the detection of $\alpha \mathrm{Ca}_{3}\left(\mathrm{PO}_{4}\right)_{3}$ in the phase transition process.

\subsection{2. $\beta$ TCP Substituted with Foreign Ions}

Among non-apatitic CaPs, the most thoroughly investigated material considering ionic substitution is $\beta$ TCP [108-116]. In turn, magnesium is definitely the most widely incorporated dopant into its crystal lattice [108,109,111,112,115-119,121-125]. The most ubiquitous method of obtaining Mg-substituted $\beta$ TCP is annealing already precipitated CDHA powders modified with $\mathrm{Mg}^{2+}$. Analysing the behaviour of these materials during heat treatment, several main trends may be observed. Introducing $\mathrm{Mg}^{2+}$ lowers the thermal stability of HA and therefore facilitates CDHA's transformation into $\beta$ TCP. In study [118] the process occurred within the temperature range of 600 to $700^{\circ} \mathrm{C}$ in case of $\mathrm{Mg}$-substituted CDHA, whereas in the absence of the dopant, the phase transition took place at higher temperatures (700 to $800^{\circ} \mathrm{C}$ ). Introducing magnesium into $\beta \mathrm{Ca}_{3}\left(\mathrm{PO}_{4}\right)_{3}$ suppresses $\beta$ to $\alpha$ phase transformation. Marchi et al. proved that the addition of at least $1.5 \mathrm{~mol} \%$ is enough to retard the above process [119].

The maximum substitution of $\mathrm{Mg}^{2+}$ in $\mathrm{Ca}^{2+}$ sites has been also examined and varies from 14 to $15 \mathrm{~mol} \%[115,116]$. Mg ions occupy $\mathrm{Ca}(4)$ and $\mathrm{Ca}(5)$ sites in the crystal structure. Successful attempts were made to create interconnected micro and macroporous Mg-substituted $\beta \mathrm{TCP}$ scaffolds.

In study [123], porous structures were obtained as an effect of the in situ foaming of the examined slurry. $\mathrm{NH}_{4} \mathrm{HCO}_{3}$ was used as a foaming factor. Subsequently, the viscous mass was sintered at $1150{ }^{\circ} \mathrm{C}$ for two hours. The field emission scanning electron microscopy (FESEM) images of these prepared materials are presented below (see Figure 7).

Another method to create $\beta$ TCP—based porous scaffolds was applied in study [122]. Briefly, $\beta$ MgTCP powder was made into slurry with distilled water and polyvinyl alcohol. Subsequently, polyurethane foams were soaked in the previously prepared slurry (see Figure 2) [122]. The excessive slurry was removed by squeezing. The soaked foams were dried and put under a heat treatment of above $1500{ }^{\circ} \mathrm{C}$. The sintering 
temperature was higher than the $\beta$ to $\alpha \mathrm{TCP}$ transition temperature. The results of the study showed that the addition of magnesium was crucial to prevent the transformation during heat treatment.

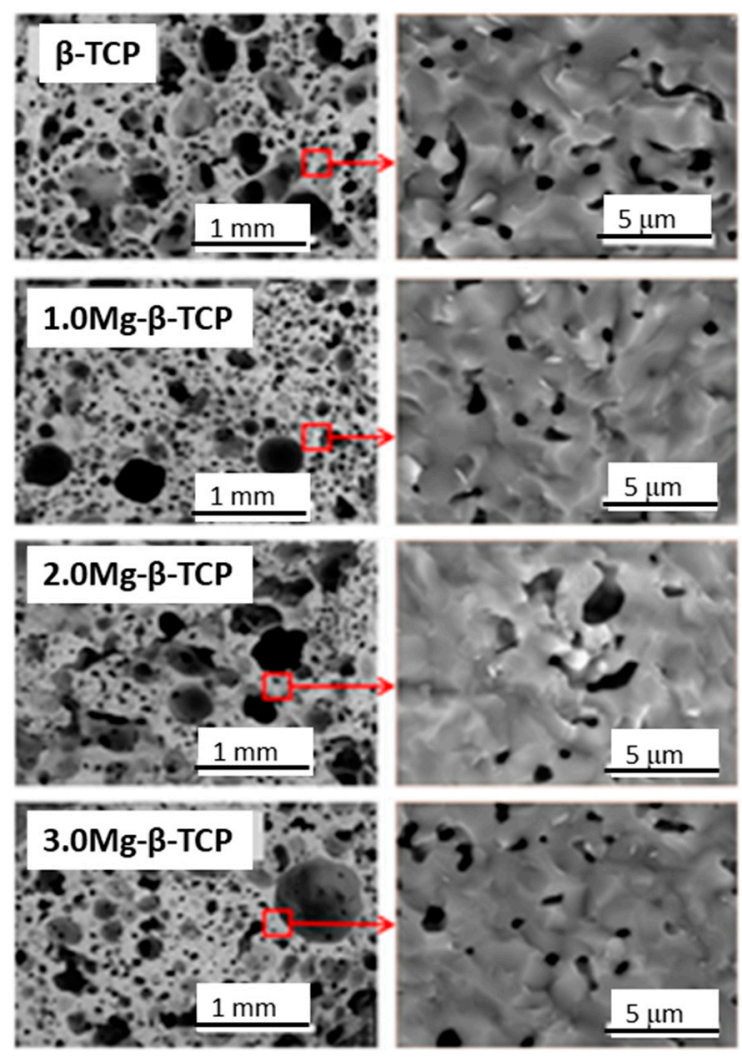

Figure 7. FESEM images Mg-containing micro-macroporous scaffolds fracture surfaces. Reprinted from [123] with permission from Elsevier.

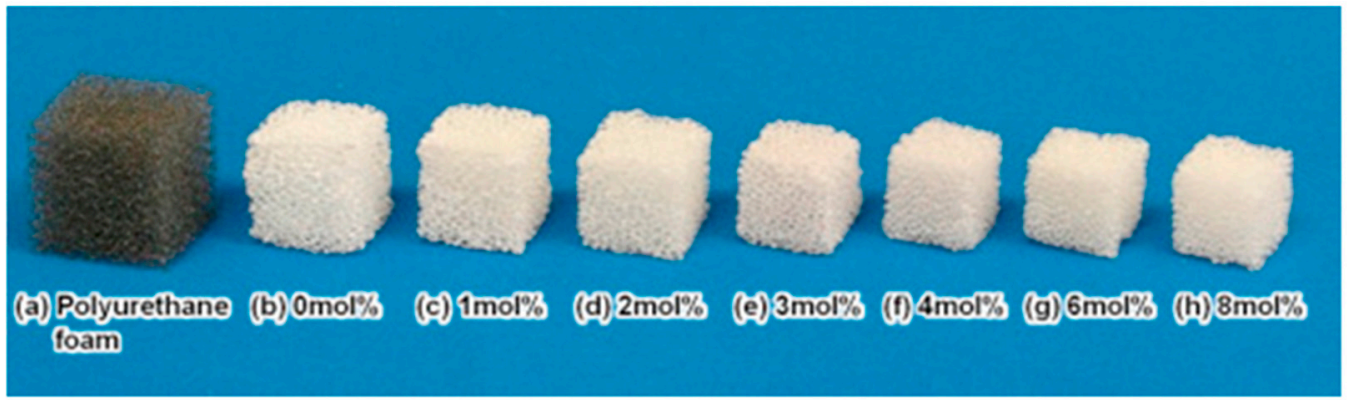

Figure 8. Typical macroscopic structure of: (a) the polyurethane foam template and (b-h) TCP foams prepared with calcium phosphate slurries containing different amounts of MgO. Reprinted from [122] with permission from Elsevier.

It is not only magnesium that is being introduced into the $\beta \mathrm{TCP}$ crystal lattice. In the literature, following examples of other ionic modifications can be found: sodium [127,143], potassium [128], silver [135], manganese [132], silicon [111,133], strontium [107,112-114], copper [136], cobalt [137], aluminium [146], iron [139-141], lantanium [131], and rare earth elements [145].

Divalent cobalt ions $\left(\mathrm{Co}^{2+}\right)$ were introduced into the $\beta$ TCP structure due to their potential induction of angiogenesis process [137]. The physicochemical and biological properties of the obtained materials containing 2 and $5 \mathrm{~mol} \%$ of $\mathrm{Co}^{2+}$ were analysed. The results suggested that, similarly to magnesium, the addition of cobalt ions stabilizes the $\beta$ TCP phase. The samples performed also low toxicity and stimulated significantly the synthesis of the vascular endothelial growth factor (VEGF). 
In turn, studies conducted by Kannan et al. [126-128] investigated the influence of sodium, potassium and chlorine on $\mathrm{CaP}$ formation. Firstly, aqueous precipitation was applied to obtain CDHA modified with $\mathrm{Na}^{+}, \mathrm{K}^{+}$or $\mathrm{Cl}^{-}$. $\mathrm{NaNO}_{3}, \mathrm{KNO}_{3}$ or $\mathrm{NH}_{4} \mathrm{Cl}$ were used as sources of dopants. The prepared powders were calcified at the temperature of $800{ }^{\circ} \mathrm{C}$. Physicochemical studies confirmed successful ionic incorporation in each case. The resulting materials were biphasic mixtures consisting of HA and $\beta$ TCP modified with the appropriate elements. The main effect of introducing monovalent ions into the HA crystal lattice was an increase in its thermal stability to the temperature of between 1200 and $1300{ }^{\circ} \mathrm{C}$ [127].

Recent works also focused on iron-doped $\beta$ TCP [139-141]. Considering the fact that CPCs substituted with magnetic ions (i.e., $\mathrm{Fe}^{3+}$ ) exhibit ferromagnetic properties, they may be used as heat mediators in hyperthermia treatment of tumors, drug delivery systems or biomaterials for magnetic resonance imaging (MRI) [141]. The studies provided by Singh et al. [140] indicated that addition of the $\mathrm{Fe}^{3+}$ ions preserved the structural stability of $\beta$ TCP. The limit of iron substitution was found to be $5.02 \mathrm{~mol} \%$. It was also shown that only high content of $\mathrm{Fe}^{3+}$ ions introduced into $\beta$ TCP structure may produce pronounced hyperthermia effect. Detailed studies on ferric doping mechanism was presented in [141]. Hyperthermia effect was investigated on $\mathrm{Fe}^{3+} / \mathrm{Ni}^{2+}$ co-substituted $\beta$ TCP [139]. High nickel content exhibited significant cytotoxicity. However, iron and nickel co-substitution displayed optimal hyperthermia effect.

The potential antibacterial activity of $\beta$ TCP substituted with appropriate ions was also investigated. Gokcekaya et al. [135] and Rau et al. [136] provided data considering the activity of Ag $\beta \mathrm{TCP}$ and $\mathrm{Cu} \beta \mathrm{TCP}$, respectively. Small amounts of silver or copper ions were nontoxic for human cells and effectively lethal for bacteria. Moreover, in one of the studies, Matsumoto et al. [129] presented the effects of co-doping $\beta T C P$ with monovalent and divalent antibacterial ions. They introduced $\mathrm{Ag}^{+}$and $\mathrm{Cu}^{2+}$ or $\mathrm{Zn}^{2+}$ using a solid-state method. The $\mathrm{Ag}^{+}$concentration was constant and maintained at the level of $9.09 \mathrm{~mol} \%$, while the amount of $\mathrm{Cu}^{2+}$ or $\mathrm{Zn}^{2+}$ varied from 0 to $15 \mathrm{~mol} \%$. The antibacterial activity of synthesized materials against S. aureus and E. coli was evaluated. Interestingly, co-doped powders exhibited better antibacterial effect than AgTCP and pure TCP. What is more, the release rates of the ions from CuAgTCP and ZnAgTCP were slower than in case of AgTCP and unsubstituted TCP. Hence, the results of the study strongly suggest that co-doped materials can be used over a long period of time, exhibiting a good antibacterial activity [129].

Not only antibacterial ions are being introduced into $\beta$ TCP. Scientific research is also focused on loading porous, modified $\beta$ TCP nanoparticles with drugs, which are commonly used to treat hard tissue infections [114,124]. An interesting method to obtain porous, doxycycline loaded material was applied in study [124]. Mesoporous $\mathrm{Mg} \beta \mathrm{TCP}$ nanospheres were obtained from amorphous $\mathrm{Mg}_{2} \mathrm{P}_{2} \mathrm{O}_{7}$ using EDTA ions as a nucleating factor. Subsequently, the prepared material was loaded with the antibiotic by immersion. The nanoparticles exhibited sustained drug release and easy cell reuptake [124].

A simultaneous introduction of more than one element into $\beta$ TCP structure is also being investigated. In studies [142,143], magnesium ions were co-substituted together with strontium [142] or sodium ions [143]. All the structures were determined using detailed X-ray diffractometry and Rietveld analysis. The obtained results showed that $\mathrm{Mg}^{2+}$ ions play the crucial role in the significant reduction of the $a$ and $c$ axis lengths. It was also revealed that $\mathrm{Sr}^{2+}$ occupy $\mathrm{Ca}(1,2,3,4)$ sites whereas $\mathrm{Mg}^{2+}$ is located at the six fold coordinated $\mathrm{Ca}(5)$ site [142]. Thermal stability as well as the limit of substitution was examined. An interesting work was presented by Meenambal et al. [144]. A simultaneous substitution of $\mathrm{Gd}^{3+}$ and $\mathrm{Dy}^{3+}$ into the $\beta$ TCP crystals was investigated. The substitution limit for co-substituted ions was determined as ca. $2.2 \mathrm{~mol} \%$ and was sufficient to exhibit paramagnetic effects. Biological tests revealed negligible toxicity of the obtained materials. Therefore, this new material may find potential application as multifunctional bioprobe or a contrast agent in MRI and CT (Computer Tomography) [144]. The simultaneous introduction of more than two ions into the $\beta$ TCP crystal lattice has been also conducted. Bose et al. [108] applied a solid-state technique to obtain $\beta \mathrm{Ca}_{3}\left(\mathrm{PO}_{4}\right)_{3}$ modified with magnesium, strontium, and silicon ions at the same time. $\mathrm{SrO}, \mathrm{MgO}$, and $\mathrm{SiO}_{2}$ were used as dopants sources. 


\section{Conclusions}

The ideal bioceramics for bone grafting must combine several biological properties such as bioactivity, biocompatibility, osteoconductivity, and non-immunogenicity. Moreover, these materials should possess mechanical resistance together with suitable resorbability, which allows for bone remodelling and new bone formation.

Different strategies can be taken to improve the biological properties of $\mathrm{CaP}$ bioceramics. One of them is to enrich the materials with particular ions, which, even in small amounts, have significant impact on the osseous cell activity, mechanical and thermal properties and solubility.

This review provides evidence for the growing interest in substituted, non-apatitic CaPs. Until now, this research has focused on these ions, which are favourable considering the biocompatibility, bioactivity, and osteointegration of synthesized materials. There has not yet been sufficient investigation in the field of ionic substitution providing biological properties i.e., antimicrobial or anticarcinogenic. We think that co-substitution in non-apatitic CaPs may represent a considerable field of scientific research, too.

Acknowledgments: This work was supported by the research programme (UMO-2016/22/E/ST5/00564) of the National Science Center, Poland.

Conflicts of Interest: The authors declare no conflict of interest.

\section{References}

1. Dorozhkin, S.V. Nanosized and nanocrystalline calcium orthophosphates. Acta Biomater. 2010, 6, 715-734. [CrossRef] [PubMed]

2. Boanini, E.; Gazzano, M.; Bigi, A. Ionic substitutions in calcium phosphates synthesized at low temperature. Acta Biomater. 2010, 6, 1882-1894. [CrossRef] [PubMed]

3. Dubnika, A.; Loca, D.; Rudovica, V.; Parekh, M.B.; Berzina-Cimdina, L. Functionalized silver doped hydroxyapatite scaffolds for controlled simultaneous silver ion and drug delivery. Ceram. Int. 2017, 43, 3698-3705. [CrossRef]

4. Jafari, S.; Maleki-Dizaji, N.; Barar, J.; Barzegar-Jalali, M.; Rameshrad, M.; Adibkia, K. Methylprednisolone acetate-loaded hydroxyapatite nanoparticles as a potential drug delivery system for treatment of rheumatoid arthritis: In vitro and in vivo evaluations. Eur. J. Pharm. Sci. 2016, 91, 225-235. [CrossRef] [PubMed]

5. Yu, W.-L.; Sun, T.-W.; Qi, C.; Zhao, H.-K.; Ding, Z.-Y.; Zhang, Z.-W.; Sun, B.-B.; Shen, J.; Chen, F.; Zhu, Y.-J.; et al. Enhanced osteogenesis and angiogenesis by mesoporous hydroxyapatite microspheres derived simvastatin sustained release system for superior bone regeneration. Sci. Rep. 2017, 7. [CrossRef] [PubMed]

6. Kolanthai, E.; Ganesan, K.; Epple, M.; Kalkura, S.N. Synthesis of nanosized hydroxyapatite/agarose powders for bonefiller and drug delivery application. Mater. Today Commun. 2016, 8, 31-40. [CrossRef]

7. Terukina, T.; Saito, H.; Tomita, Y.; Hattori, Y.; Otsuka, M. Development and effect of a sustainable and controllable simvastatin releasing device based on PLGA microspheres/carbonate apatite cement composite: In vitro evaluation for use as a drug delivery system from bone-like biomaterial. J. Drug Deliv. Sci. Technol. 2017, 37, 74-80. [CrossRef]

8. Lei, Y.; Xu, Z.; Ke, Q.; Yin, W.; Chen, Y.; Zhang, C.; Guo, Y. Strontium hydroxyapatite/chitosan nanohybrid scaffolds with enhanced osteoinductivity for bone tissue engineering. Mater. Sci. Eng. C 2017, 72, 134-142. [CrossRef] [PubMed]

9. Supova, M. Substituted hydroxyapatites for biomedical applications: A review. Ceram. Int. 2015, 41, 9203-9231. [CrossRef]

10. Shepherd, J.H.; Shepherd, D.V.; Best, S.M. Substituted hydroxyapatites for bone repair. J. Mater. Sci. Mater. Med. 2012, 23, 2335-2347. [CrossRef] [PubMed]

11. Li, Y.; Widodo, J.; Lim, S.; Ooi, C.P. Synthesis and cytocompatibility of manganese (II) and iron (III) substituted hydroxyapatite nanoparticles. J. Mater. Sci. 2012, 47, 754-763. [CrossRef]

12. Wang, Y.; Hao, H.; Li, Y.; Zhang, S. Selenium-substituted hydroxyapatite nanoparticles and their in vivo antitumor effect on hepatocellular carcinoma. Colloids Surf. B Biointerfaces 2016, 140, 297-306. [CrossRef] 
13. Mourino, V.; Cattalini, J.P.; Boccaccini, A.R. Metallic ions as therapeutic agents in tissue engineering scaffolds: An overview of their biological applications and strategies for new developments. J. R. Soc. Interface 2012, 9, 401-419. [CrossRef] [PubMed]

14. Kolmas, J.; Groszyk, E.; Kwiatkowska-Różycka, D. Substituted hydroxyapatites with antibacterial properties. BioMed Res. Int. 2014, 2014. [CrossRef] [PubMed]

15. Ratnayake, J.T.B.; Mucalo, M.; Dias, G.J. Substituted hydroxyapatites for bone regeneration: A review of current trends. J. Biomed. Mater. Res. B 2017, 105, 1285-1299. [CrossRef] [PubMed]

16. Graziani, G.; Bianchi, M.; Sassoni, E.; Russo, A.; Marcacci, M. Ion-substituted calcium phosphate coatings deposited by plasma-assisted techniques: A review. Mater. Sci. Eng. C 2017, 74, 219-229. [CrossRef] [PubMed]

17. Combes, C.; Cazalbou, S.; Rey, C. Apatite biominerals. Minerals 2016, 6, 34. [CrossRef]

18. Alshemary, Z.; Akrama, M.; Goh, Y.-F.; Tariq, U.; Butt, F.K.; Abdolahi, A.; Hussain, R. Synthesis, characterization, in vitro bioactivity and antimicrobial activity of magnesium and nickel doped silicate hydroxyapatite. Ceram. Int. 2015, 41, 11886-11898. [CrossRef]

19. Castiglioni, S.; Cazzaniga, A.; Albisetti, W.; Maier, J.A.M. Magnesium and Osteoporosis: Current State of Knowledge and Future Research Directions. Nutrients 2013, 5, 3022-3033. [CrossRef] [PubMed]

20. Rude, R.K.; Singer, F.R.; Gruber, H.E. Skeletal and Hormonal Effects of Magnesium Deficiency. J. Am. Coll. Nutr. 2009, 28, 131-141. [CrossRef] [PubMed]

21. He, L.Y.; Zhang, X.M.; Liu, B.; Tian, Y.; Ma, W.H. Effect of magnesium ion on human osteoblast activity. Braz. J. Med. Biol. Res. 2016, 49, 1414-1431. [CrossRef] [PubMed]

22. Smith, B.J.; Hermann, J. Aging, zinc, and bone health. In Bioactive Food as Dietary Interventions for the Aging Population; Watson, R.R., Preedy, V.R., Eds.; Academic Press: San Diego, CA, USA, 2013; pp. 433-443.

23. Shepherd, D. Zinc-substituted hydroxyapatite for the inhibition of osteoporosis. In Hydroxyapatite (HAp) in Biomedical Applications; Mucalo, M., Ed.; Woodhead Publishing: Cambridge, UK, 2015; pp. 107-126.

24. Kwiecień, M.; Winiarska-Mieczan, A.; Milczarek, A.; Tomaszewska, E.; Matras, J. Effects of zinc glycine chelate on growth performance, carcass characteristics, bone quality, and mineral content in bone of broiler chicken. Livest. Sci. 2016, 191, 43-50. [CrossRef]

25. Hadley, K.B.; Newman, S.M.; Hunt, J.R. Dietary zinc reduces osteoclast resorption activities and increases markers of osteoblast differentiation, matrix maturation, and mineralization in the long bones of growing rats. J. Nutr. Biochem. 2010, 21, 297-303. [CrossRef] [PubMed]

26. Querido, W.; Rossi, A.L.; Farina, M. The effects of strontium on bone mineral: A review on current knowledge and microanalytical approaches. Micron 2016, 80, 122-134. [CrossRef] [PubMed]

27. Kaygili, O.; Keser, S.; Kom, M.; Eroksuz, Y.; Dorozhkin, S.V.; Ates, T.; Ozercan, I.H.; Tatar, C.; Yakuphanoglu, F. Strontium substituted hydroxyapatites: Synthesis and determination of their structural properties, in vitro and in vivo performance. Mater. Sci. Eng. C 2015, 55, 538-546. [CrossRef] [PubMed]

28. Bonnelye, E.; Chabadel, A.; Saltel, F.; Jurdic, P. Dual effect of strontium ranelate: Stimulation of osteoblast differentiation and inhibition of osteoclast formation and resorption in vitro. Bone 2008, 42, 129-138. [CrossRef] [PubMed]

29. Tat, K.S.; Pelletier, J.P.; Mineau, F.; Caron, J.; Martel-Pelletier, J. Strontium ranelate inhibits key factors affecting bone remodeling in human osteoarthritic subchondral bone osteoblasts. Bone 2011, 49, 559-567. [CrossRef] [PubMed]

30. Pasqualetti, S.; Banfi, G.; Mariotti, M. The effects of strontium on skeletal development in zebrafish embryo. J. Trace Elem. Med. Biol. 2013, 27, 375-379. [CrossRef] [PubMed]

31. Reginster, J.Y.; Neuprez, A.; Dardenne, N.; Beaudart, C.; Emonts, P.; Bruyere, O. Efficacy and safety of currently marketed antiosteoporosis medications. Best Pract. Res. Clin. Endocrinol. Metab. 2014, 28, 809-834. [CrossRef] [PubMed]

32. Jurkić, M.L.; Cepanec, I.; Pavelić, S.K.; Pavelić, K. Biological and therapeutic effects of ortho-silicic acid and some ortho-silicic acid-releasing compounds: New perspectives for therapy. Nutr. Metab. 2013, 10, 1-12. [CrossRef] [PubMed]

33. Carlisle, E.M. Silicon: A Possible Factor in Bone Calcification. Science 1970, 167, 279-280. [CrossRef] [PubMed]

34. Carlisle, E.M. Silicon: An essential element for the chick. Science 1972, 178, 619-621. [CrossRef] [PubMed]

35. Carlisle, E.M. Silicon: A requirement in bone formation independent of vitamin $\mathrm{D}_{1}$. Calcif. Tissue Int. 1981, 33, 27-34. [CrossRef] [PubMed] 
36. Carlisle, E.M. Silicon as an essential trace element in animal nutrition. Ciba Found. Symp. 1986, 121, $123-139$. [CrossRef] [PubMed]

37. Reffitt, D.M.; Ogston, N.; Jugdaohsingh, R.; Cheung, H.F.J.; Evans, B.A.J.; Thompson, R.P.H.; Powell, J.J.; Hampson, G.N. Orthosilicic acid stimulates collagen type 1 synthesis and osteoblastic differentiation in human osteoblast-like cells in vitro. Bone 2003, 32, 127-135. [CrossRef]

38. Spector, T.D.; Calomme, M.R.; Anderson, S.H.; Clement, G.; Bevan, L.; Demeester, N.; Swaminathan, R.; Jugdaohsingh, R.; Berghe, D.A.; Powell, J.J. Choline-stabilized orthosilicic acid supplementation as an adjunct to Calcium/Vitamin D3 stimulates markers of bone formation in osteopenic females: A randomized, placebo-controlled trial. BMC Muscoskelet. Dis. 2008, 9, 1-10. [CrossRef] [PubMed]

39. Camaioni, A.; Cacciotti, I.; Campagnolo, L.; Bianco, A. Silicon-substituted hydroxyapatite for biomedical applications. In Hydroxyapatite (HAp) in Biomedical Applications; Mucalo, M., Ed.; Woodhead Publishing: Cambridge, UK, 2015; pp. 333-373.

40. Jugdaohsingh, R.; Tucker, K.L.; Qiao, N.; Cupples, L.A.; Kiel, D.P.; Powell, J.J. Dietary Silicon Intake is Positively Associated with Bone Mineral Density in Men and Premenopausal Women of the Framingham Offspring Cohort. J. Bone Miner. Res. 2004, 19, 297-307. [CrossRef] [PubMed]

41. Judgaohsingh, R. Silicon and Bone Health. J. Nutr. Health Aging 2007, 11, 99-110.

42. Henstock, J.R.; Canham, L.T.; Anderson, S.I. Silicon: The evolution of its use in biomaterials. Acta Biomater. 2015, 11, 17-26. [CrossRef] [PubMed]

43. Dorozhkin, S.V.; Epple, M. Biological and Medical Significance of Calcium Phosphates. Angew. Chem. Int. Ed. Engl. 2002, 41, 3130-3146. [CrossRef]

44. LeGeros, Z.R.; Ito, A.; Ishikawa, K.; Sakae, T.; LeGeros, J.P. Fundamentals of Hydroxyapatite and Related Calcium Phosphates. In Advanced Biomaterials; Basu, B., Katti, D.S., Kumar, A., Eds.; Wiley: Newark, NJ, USA, 2009; pp. 19-52.

45. Chow, L.C. Solubility of Calcium Phosphates. In Octacalcium Phosphate; Chow, L.C., Eanes, E.D., Eds.; Karger: Basel, Switzerland, 2001; Volume 18, pp. 94-111.

46. Du, L.-W.; Bian, S.; Gou, B.-D.; Jiang, Y.; Huang, J.; Gao, Y.-X.; Zhao, Y.-D.; Wen, W.; Zhang, T.-L.; Wang, K. Structure of Clusters and Formation of Amorphous Calcium Phosphate and Hydroxyapatite: From the Perspective of Coordination Chemistry. Cryst. Growth Des. 2013, 13, 3103-3109. [CrossRef]

47. Elliott, J.C. Structure and Chemistry of the Apatites and Other Calcium Orthophosphates; Elsevier Science: Amsterdam, The Netherlands, 1994; pp. 53-61.

48. Combes, C.; Rey, C. Amorphous calcium phosphates: Synthesis, properties and uses in biomaterials. Acta Biomater. 2010, 6, 3362-3378. [CrossRef] [PubMed]

49. Dorozhkin, S.V. Amorphous calcium (ortho) phosphates. Acta Biomater. 2016, 6, 4457-4475. [CrossRef] [PubMed]

50. Habraken, W.; Habibovic, P.; Epple, M.; Bohner, M. Calcium phosphates in biomedical applications: Materials for the future? Mater. Today 2016, 19, 69-87. [CrossRef]

51. Lee, D.; Kumta, P.N. Chemical synthesis and stabilization of magnesium substituted brushite. Mater. Sci. Eng. C 2010, 30, 934-943. [CrossRef]

52. Ferreira, A.; Oliveira, C.; Rocha, F. The different phases in the precipitation of dicalcium phosphate dehydrate. J. Cryst. Growth 2003, 252, 599-611. [CrossRef]

53. Oliveira, A.; Ferreira, A.; Rocha, F. Dicalcium Phosphate Dihydrate: Precipitation Characterization and Crystal Growth. Chem. Eng. Res. Des. 2007, 85, 1655-1661. [CrossRef]

54. Chen, G.G.; Luo, G.S.; Yang, L.M.; Xu, J.H.; Sun, Y.; Wang, J.D. Synthesis and size control of CaHPO $\mathrm{Particles}$ in a two-liquid phase micro-mixing process. J. Cryst. Growth 2005, 279, 501-507. [CrossRef]

55. Kumta, P.N.; Sfeir, C.; Lee, D.-H.; Olton, D.; Choi, D. Nanostructured calcium phosphates for biomedical applications: Novel synthesis and characterization. Acta Biomater. 2005, 1, 65-83. [CrossRef] [PubMed]

56. Ginebra, M.-P.; Canal, C.; Espanol, M.; Pastorino, D.; Montufar, E.B. Calcium phosphate cements as drug delivery materials. Adv. Drug Deliv. Rev. 2012, 64, 1090-1110. [CrossRef] [PubMed]

57. Vallet-Regí, M.; González-Calbet, J.M. Calcium phosphates as substitution of bone tissues. Prog. Solid State Chem. 2004, 32, 1-31. [CrossRef]

58. Dorozhkin, S.V. Bioceramics of calcium orthophosphates. Biomaterials 2010, 31, 1465-1485. [CrossRef] [PubMed]

59. Kwon, S.-H.; Jun, Y.-K.; Hong, S.-H.; Kim, H.-E. Synthesis and dissolution behavior of $\beta$-TCP and HA/b-TCP composite powders. J. Eur. Ceram. Soc. 2003, 23, 1039-1045. [CrossRef] 
60. Kolmas, J.; Kaflak, A.; Zima, A.; Slosarczyk, A. Alpha-tricalcium phosphate synthesized by two different routes: Structural and spectroscopic characterization. Ceram. Int. 2015, 41, 5727-5733. [CrossRef]

61. Carrodeguas, R.G.; De Aza, S. $\alpha$-Tricalcium phosphate: Synthesis, properties and biomedical applications. Acta Biomater. 2011, 7, 3536-3546. [CrossRef] [PubMed]

62. Somrani, S.; Rey, C.; Jemal, M. Thermal evolution of amorphous tricalcium phosphate. J. Mater. Chem. 2003, 13, 888-892. [CrossRef]

63. Camiré, C.L.; Jegou, S.J.S.; Hansen, S.; McCarthy, I.; Lidgren, L. Hydration characteristics of $\alpha$-tricalcium phosphates: Comparison of preparation routes. J. Appl. Biomater. Biomech. 2005, 3, 106-111. [PubMed]

64. Jokic, B.; Jankovic-Castvan, I.; Veljovic, D.; Bucevac, D.; Obradovic-Djuricic, K.; Petrovic, R. Synthesis and settings behavior of alpha-TCP from calcium deficient hyroxyapatite obtained by hydrothermal method. J. Optoelectron. Adv. Mater. 2007, 9, 1904-1910.

65. Bohner, M.; Brunner, T.J.; Doebelin, N.; Tang, R.K.; Stark, W.J. Effect of thermal treatments on the reactivity of nanosized tricalcium phosphate powders. J. Mater. Chem. 2008, 18, 4460-4467. [CrossRef]

66. Döbelin, N.; Brunner, T.J.; Stark, W.J.; Eggimann, M.; Fisch, M.; Bohne, M. Phase evolution of thermally treated amorphous tricalcium phosphate nanoparticles. Key Eng. Mater. 2009, 396-398, 595-598. [CrossRef]

67. Famery, R.; Richard, N.; Boch, P. Preparation of $\alpha$ - and $\beta$-tricalcium phosphate ceramics, with and without magnesium addition. Ceram. Int. 1994, 20, 327-336. [CrossRef]

68. Durucan, C.; Brown, P.W. Reactivity of $\alpha$-tricalcium phosphate. J. Mater. Sci. 2002, 37, 963-969. [CrossRef]

69. Cai, S.; Wang, Y.W.; Li, J.Y.; Guan, Y.H.; Yao, K.D. Effects of dispersed medium and mineralizer $\mathrm{CaF}_{2}$ on the synthesis of alpha-tricalcium phosphate. J. Inorg. Mater. 2004, 19, 852-858.

70. Camiré, C.L.; Gbureck, U.; Hirsiger, W.; Bohner, M. Correlating crystallinity and reactivity in $\alpha$-tricalcium phosphate. Biomaterials 2005, 26, 2787-2794. [CrossRef] [PubMed]

71. Wei, X.; Ugurlu, O.; Akinc, A. Hydrolysis of $\alpha$-tricalcium phosphate in simulated body fluid and dehydration behaviour during the drying process. J. Am. Ceram. Soc. 2007, 90, 2315-2321. [CrossRef]

72. Burkes, D.E.; Moore, J.J.; Ayers, R.A. Method for Producing Calcium Phosphate Powders Using an Auto-Ignition Combustion Synthesis Reaction. U.S. Patent Application No. 11/848,520, 15 May 2008.

73. Ayers, R.A.; Simske, S.J.; Moore, J.J.; Castillo, M.; Gottoli, G. Manufacture of Porous Net-Shaped Materials Comprising Alpha or Beta Tricalcium Phosphate or Mixtures Thereof. U.S. Patent Application No. 8,545,786, 1 October 2013.

74. Ayers, R.; Nielsen-Preiss, S.; Ferguson, V.; Gotolli, G.; Moore, J.J.; Kleebe, H.-J. Osteoblast-like cell mineralization induced by multiphasic calcium phosphate ceramic. Mater. Sci. Eng. C 2006, 26, 1333-1337. [CrossRef]

75. Volkmer, T.M.; Bastos, L.L.; Sousa, V.C.; Santos, L.A. Obtainment of alpha-tricalcium phosphate by solution combustion synthesis method using urea ascombustible. Key Eng. Mater. 2009, 396-398, 591-594. [CrossRef]

76. Ghosh, R.; Sarkar, R. Synthesis and characterization of sintered beta-tricalcium phosphate: A comparative study on the effect of preparation route. Mater. Sci. Eng. C 2016, 67, 345-352. [CrossRef] [PubMed]

77. Sanosh, K.P.; Chu, M.-C.; Balakrishnan, A.; Kim, T.N.; Cho, S.-J. Sol-gel synthesis of pure nanosized $\beta$-tricalcium phosphate crystalline powders. Curr. Appl. Phys. 2010, 10, 68-71. [CrossRef]

78. Thomas, D.; Su, S.; Qiu, J.; Pantoya, M.L. Microwave synthesis of functionally graded tricalcium phosphate for osteoconduction. Mater. Today 2016, 9, 47-53. [CrossRef]

79. Nabiyouni, M.; Ren, Y.; Bhaduri, S.B. Magnesium substitution in the structure of orthopaedic nanoparticles: A comparison between amorphous magnesium phosphates, calcium magnesium phosphates and hydroxyapatites. Mater. Sci. Eng. C 2015, 52, 11-17. [CrossRef] [PubMed]

80. Dong, G.; Zheng, Y.; He, L.; Wu, G.; Deng, C. The effect of silicon doping on the transformation of amorphous calcium phosphate to silicon-substituted $\alpha$-tricalcium phosphate by heat treatment. Ceram. Int. 2016, 42, 883-890. [CrossRef]

81. Kato, N.; Hatoko, Y.; Yamamoto, E.; Furuzono, T.; Hontsu, S. Preparation and application of a potassium-substituted calcium phosphate sheet as a dental material for treating dentin hypersensitivity. Key Eng. Mater. 2017, 720, 102-107. [CrossRef]

82. Yu, T.; Gao, C.; Ye, J.; Zhang, M. Synthesis and characterization of a novel silver-substituted calcium phosphate cement. J. Mater. Sci. Technol. 2014, 30, 686-691. [CrossRef]

83. Alkhraisat, M.H.; Cabrejos-Azama, J.; Rodríguez, C.R.; Blanco Jerez, L.; López-Cabarcos, E. Magnesium substitution in brushite cements. Mater. Sci. Eng. C 2013, 33, 475-481. [CrossRef] [PubMed] 
84. Cabrejos-Azama, J.; Alkhraisat, M.H.; Rueda, C.; Torres, J.; Blanco, L.; López-Cabarcos, E. Magnesium substitution in brushite cements for enhanced bone tissue regeneration. Mater. Sci. Eng. C 2014, 43, 403-410. [CrossRef] [PubMed]

85. Cabrejos-Azama, J.; Alkhraisat, M.H.; Rueda, C.; Torres, J.; Pintado, C.; Blanco, L.; López-Cabarcos, E. Magnesium substitution in brushite cements: Efficacy of a new biomaterial loaded with vancomycin for the treatment of Staphylococcus aureus infections. Mater. Sci. Eng. C 2016, 61, 72-78. [CrossRef] [PubMed]

86. Saleh, T.; Ling, L.S.; Hussain, R. Injectable magnesium-doped brushite cement for controlled drug release application. J. Mater. Sci. 2016, 51, 7427-7439. [CrossRef]

87. Geffers, M.; Barralet, J.E.; Groll, J.; Gbureck, U. Dual-setting brushite-Silica gel cements. Acta Biomater. 2015, 11,467-476. [CrossRef] [PubMed]

88. Alkhraisat, M.H.; Mariño, F.T.; Rodríguez, C.R.; Jerez, L.B.; Cabarcos, E.L. Combined effect of strontium and pyrophosphate on the properties of brushite cements. Acta Biomater. 2008, 4, 664-670. [CrossRef] [PubMed]

89. Alkhraisat, M.H.; Rueda, C.; Cabarcos, E.L. Strontium ion substitution in brushite crystals: The role of strontium chloride. J. Funct. Biomater. 2011, 2, 31-38. [CrossRef] [PubMed]

90. Ewald, A.; Kappel, C.; Vorndran, E.; Moseke, C.; Gelinsky, M.; Gbureck, U. The effect of Cu(II)-loaded brushite scaffolds on growth and activity of osteoblastic cells. J. Biomed. Mater. Res. A 2012, 100, 2392-2400. [CrossRef] [PubMed]

91. Nishikawa, H.; Honda, M.; Yokota, T.; Shimizu, Y.; Aizawa, M. Preparation of Spherical Zn-Substituted Tricalcium Phosphate Powder by Ultrasonic Spray-Pyrolysis Technique and Its Characterization. J. Nanomater. 2016, 2016, 1-8. [CrossRef]

92. El-dek, S.I.; Mansour, S.F.; Ahmed, M.A.; Ahmed, M.K. Microstructural feature of flower like Fe brushite. Prog. Nat. Sci. 2017, 27, 520-526. [CrossRef]

93. Guerra-López, J.R.; Güida, J.A.; Ramos, G.; Punte, M. The influence of nickel on brushite structure stabilization. J. Mol. Struct. 2017, 1137, 720-724. [CrossRef]

94. Correia, M.B.; Junior, J.P.G.; Macedo, M.C.S.S.; Resende, C.X.; dos Santos, E.A. Effect of $\mathrm{Mg}^{2+}$ on acidic calcium phosphate phases grown by electrodeposition. J. Cryst. Growth 2017, 475, 328-333. [CrossRef]

95. Torres, P.M.C.; Marote, A.; Cerqueira, A.R.; Calado, A.J.; Abrantes, J.C.C.; Olhero, S.; da Cruz e Silva, O.A.B.; Vieira, S.I.; Ferreira, J.M.F. Injectable MnSr-doped brushite bone cements with improved biological performance. J. Mater. Chem. B 2017, 5, 2775-2787. [CrossRef]

96. Vahabzadeh, S.; Bandyopadhyay, A.; Bose, S.; Mandal, R.; Nandi, S.K. IGF-loaded silicon and zinc doped brushite cement: Physico-mechanical characterization and in vivo ostogenesis evaluation. Integr. Biol. 2015, 7, 1561-1573. [CrossRef] [PubMed]

97. Wei, X.; Akinc, M. Crystal structure analysis of Si- and Zn-codoped tricalcium phosphate by neutron powder diffraction. J. Am. Ceram. Soc. 2007, 90, 2709-2715. [CrossRef]

98. Reid, J.W.; Tuck, L.; Sayer, M.; Fargo, K.; Hendry, J.A. Synthesis and characterization of single-phase silicon-substituted $\alpha$-tricalcium phosphate. Biomaterials 2006, 27, 2916-2925. [CrossRef] [PubMed]

99. Duncan, J.; Hayakawa, S.; Osaka, A.; MacDonald, J.F.; Hanna, J.V.; Skakle, J.M.S.; Gibson, I.R. Furthering the understanding of silicate-substitution in $\alpha$-tricalcium phosphate: An X-ray diffraction, X-ray fluorescence and solid-state nuclear magnetic resonance study. Acta Biomater. 2014, 10, 1443-1450. [CrossRef] [PubMed]

100. Motisuke, M.; Mestres, G.; Reno, C.O.; Carrodeguas, R.G.; Zavaglia, C.A.C.; Ginebra, M.P. Influence of Si substitution on the reactivity of $\alpha$-tricalcium phosphate. Mater. Sci. Eng. C 2017, 75, 816-821. [CrossRef] [PubMed]

101. Kamitakahara, M.; Tatsukawa, E.; Shibata, Y.; Umemoto, S.; Yokoi, T.; Ioku, K.; Ikeda, T. Effect of silicate incorporation on in vivo responses of $\alpha$-tricalcium phosphate ceramics. J. Mater. Sci. Mater. Med. 2016, 27, 97. [CrossRef] [PubMed]

102. Mate-Sanchez de Val, J.E.; Calvo-Guirado, J.L.; Delgado-Ruiz, R.A.; Ramirez-Fernandez, M.P.; Negri, B.; Abboud, M.; Martinez, I.M.; de Aza, P.N. Physical properties, mechanical behavior, and electron microscopy study of a new $\alpha$-TCP block graft with silicon in an animal model. J. Biomed. Mater. Res. A 2012, 100, 3446-3454. [CrossRef] [PubMed]

103. Mate-Sanchez de Val, J.E.; Calvo-Guirado, J.L.; Delgado-Ruiz, R.A.; Ramirez-Fernandez, M.P.; Martinez, I.M.; Granero-Marin, J.M.; Negri, B.; Chiva-Garcia, F.; Martinez-Gonzalez, J.M.; de Aza, P.N. New block graft of $\alpha$-TCP with silicon in critical size defects in rabbits: Chemical characterization, histological, histomorphometric and micro-CT study. Ceram. Int. 2012, 38, 1563-1570. [CrossRef] 
104. Radovanovíc, P.Z.; Jokíc, B.; Veljovíc, D.; Dimitrijevíc, S.; Kojic, V.; Petrovíc, R.; Janáckovíc, A. Antimicrobial activity and biocompatibility of $\mathrm{Ag}^{+}$- and $\mathrm{Cu}^{2+}$-doped biphasic hydroxyapatite/ $\alpha$-tricalcium phosphate obtained from hydrothermally synthesized $\mathrm{Ag}^{+}$- and $\mathrm{Cu}^{2+}$-doped hydroxyapatite. Appl. Surf. Sci. 2014, 307, 513-519. [CrossRef]

105. Reid, J.W.; Fargo, K.; Hendry, J.A.; Sayer, M. The influence of trace magnesium content on the phase composition of silicon-stabilized calcium phosphate powders. Mater. Lett. 2007, 61, 3851-3854. [CrossRef]

106. Tong, C.; Zhu, Y.; Xu, C.; Li, Y. Preliminary observation of self-reduction of Eu ions in $\alpha-\mathrm{Ca}_{3}\left(\mathrm{PO}_{4}\right)_{2}$ phosphors prepared in air condition. Phys. B Condens. Matter 2016, 500, 20-23. [CrossRef]

107. Pina, S.; Torres, P.M.; Goetz-Neunhoeffer, F.; Neubauer, J.; Ferreira, J.M.F. Newly developed Sr-substituted $\alpha$-TCP bone cements. Acta Biomater. 2010, 6, 928-935. [CrossRef] [PubMed]

108. Bose, S.; Tarafder, S.; Banerjee, S.S.; Davies, N.M.; Bandyopadhyay, A. Understanding in vivo response and mechanical property variation in $\mathrm{MgO}, \mathrm{SrO}$ and $\mathrm{SiO}_{2}$ doped $\beta$-TCP. Bone 2011, 48, 1282-1290. [CrossRef] [PubMed]

109. Singh, R.K.; Kannan, S. Synthesis, Structural analysis, Mechanical, antibacterial and Hemolytic activity of $\mathrm{Mg}^{2+}$ and $\mathrm{Cu}^{2+}$ co-substitutions in $\beta-\mathrm{Ca}_{3}\left(\mathrm{PO}_{4}\right)_{2}$. Mater. Sci. Eng. C 2014, 45, 530-538. [CrossRef] [PubMed]

110. Matsumoto, N.; Sato, K.; Yoshida, K.; Hashimoto, K.; Toda, Y. Preparation and characterization of $\alpha$-tricalcium phosphate co-doped with monovalent and divalent antibacterial metal ions. Acta Biomater. 2009, 5, 3157-3164. [CrossRef] [PubMed]

111. García-Páez, H.; García Carrodeguas, R.; De Aza, A.H.; Baudín, C.; Pena, P. Effect of Mg and Si co-substitution on microstructure and strength of tricalcium phosphate ceramics. J. Mech. Behav. Biomed. Mater. 2014, 30, 1-15. [CrossRef] [PubMed]

112. Banerjee, S.S.; Tarafder, S.; Davies, N.M.; Bandyopadhyay, A.; Bose, S. Understanding the influence of $\mathrm{MgO}$ and $\mathrm{SrO}$ binary doping on the mechanical and biological properties of $\beta$-TCP ceramics. Acta Biomater. 2010, 6, 4167-4174. [CrossRef] [PubMed]

113. Bigi, A.; Foresti, E.; Gandolfi, M.; Gazzano, M.; Roveri, N. Isomorphous Substitutions in $\beta$-Tricalcium Phosphate: The Different Effects of Zinc and Strontium. J. Inorg. Biochem. 1997, 66, 259-265. [CrossRef]

114. Alkhraisat, M.H.; Rueda, C.; Cabrejos-Azama, J.; Lucas-Aparicio, J.; Marińo, F.T.; Torres García-Denche, J.; Jerez, L.B.; Gbureck, U.; Cabarcos, E.L. Loading and release of doxycycline hyclate from strontium-substituted calcium phosphate cement. Acta Biomater. 2010, 6, 1522-1528. [CrossRef] [PubMed]

115. Araújo, C.; Sader, M.S.; Moreira, E.L.; Moraes, V.C.A.; LeGeros, R.Z.; Soares, G.A. Maximum substitution of magnesium for calcium sites in Mg- $\beta$-TCP structure determined by X-ray powder diffraction with the Rietveld refinement. Mater. Chem. Phys. 2009, 118, 337-340. [CrossRef]

116. Enderle, R.; Götz-Neunhoeffer, F.; Göbbels, M.; Müller, F.A.; Greil, P. Influence of magnesium doping on the phase transformation temperature of $\beta$-TCP ceramics examined by Rietveld refinement. Biomaterials 2005, 26, 3379-3384. [CrossRef] [PubMed]

117. Kannan, S.; Ventura, J.M.; Ferreira, J.M.F. Aqueous precipitation method for the formation of Mg-stabilized $\beta$-tricalcium phosphate: An X-ray diffraction study. Ceram. Int. 2007, 33, 637-641. [CrossRef]

118. Kannan, S.; Lemos, I.A.F.; Rocha, J.H.G.; Ferreira, J.M.F. Synthesis and characterization of magnesium substituted biphasic mixtures of controlled hydroxyapatite/ $\beta$-tricalcium phosphate ratios. J. Solid State Chem. 2005, 178, 3190-3196. [CrossRef]

119. Marchi, A.; Dantas, A.C.S.; Greil, P.; Bressiani, J.C.; Bressiani, A.H.A.; Müller, F.A. Influence of Mg-substitution on the physicochemical properties of calcium phosphate powders. Mater. Res. Bull. 2007, 42, 1040-1050. [CrossRef]

120. Zhou, H.; Hou, S.; Zhang, M.; Chai, H.; Liu, Y.; Bhaduri, S.; Yang, L.; Deng, L. Synthesis of $\beta$-TCP and CPP containing biphasic calcium phosphates by a robust technique. Ceram. Int. 2016, 42, 11032-11038. [CrossRef]

121. Ryu, H.-S.; Hong, K.S.; Lee, J.-K.; Kim, D.J.; Lee, J.H.; Chang, B.-S.; Lee, D.-H.; Lee, C.-K.; Chung, S.-S. Magnesia-doped HA/ $\beta$-TCP ceramics and evaluation of their biocompatibility. Biomaterials 2004, 25, 393-401. [CrossRef]

122. Nikaido, T.; Tsuru, K.; Munar, M.; Maruta, M.; Matsuya, S.; Nakamura, S.; Ishikawa, K. Fabrication of $\beta$-TCP foam: Effects of magnesium oxide as phase stabilizer on its properties. Ceram. Int. 2015, 41, 14245-14250. [CrossRef] 
123. Salma-Ancane, A.; Stipniece, L.; Putnins, A.; Berzina-Cimdina, L. Development of Mg-containing porous $\beta$-tricalcium phosphate scaffolds for bone repair. Ceram. Int. 2015, 41, 4996-5004. [CrossRef]

124. Wang, S.; Liu, R.; Yao, J.; Wang, Y.; Li, H.; Dao, R.; Guan, J.; Tang, G. Fabrication of mesoporous magnesium substituted $\beta$-tricalcium phosphate nanospheres by self-transformation and assembly involving EDTA ions. Microporous Microporous Mater. 2013, 179, 172-181. [CrossRef]

125. Tavares, D.; Castro, L.O.; Soares, G.D.A.; Alves, G.G.; Granjeiro, J.M. Synthesis and cytotoxicity evaluation of granular magnesium substituted $\beta$-tricalcium phosphate. J. Appl. Oral Sci. 2013, 21, 37-42. [CrossRef]

126. Grigg, T.; Mee, M.; Mallinson, P.M.; Fong, S.K.; Gan, Z.; Dupree, R.; Holland, D. Cation substitution in $\beta$-tricalcium phosphate investigated using multi-nuclear, solid-state NMR. J. Solid State Chem. 2014, 212, 227-236. [CrossRef]

127. Kannan, S.; Ventura, J.M.G.; Lemos, A.F.; Barba, A.; Ferreira, J.M.F. Effect of sodium addition on the preparation of hydroxyapatites and biphasic ceramics. Ceram. Int. 2008, 34, 7-13. [CrossRef]

128. Kannan, S.; Ventura, J.M.G.; Ferreira, J.M.F. Synthesis and thermal stability of potassium substituted hydroxyapatites and hydroxyapatite/ $\beta$-tricalcium phosphate mixtures. Ceram. Int. 2007, 33, 1489-1494. [CrossRef]

129. Kannan, S.; Rebelo, A.; Lemos, A.F.; Barba, A.; Ferreira, J.M.F. Synthesis and mechanical behaviour of chlorapatite and chlorapatite/ $\beta$-TCP composites. J. Eur. Ceram. Soc. 2007, 27, 2287-2294. [CrossRef]

130. Matsumoto, A.; Yoshida, K.; Hashimoto, K.; Toda, Y. Thermal stability of $\beta$-tricalcium phosphate doped with monovalent metal ions. Mater. Res. Bull. 2009, 44, 1889-1894. [CrossRef]

131. Meenambal, R.; Singh, R.K.; Kumar, P.N.; Kannan, S. Synthesis, structure, thermal stability, mechanical and antibacterial behaviour of lanthanum $\left(\mathrm{La}^{3+}\right)$ substitutions in $\beta$-tricalcium phosphate. Mater. Sci. Eng. C 2014, 43, 598-606. [CrossRef] [PubMed]

132. Mayer, A.; Cuisinier, F.J.G.; Gdalya, S.; Popov, I. TEM study of the morphology of $\mathrm{Mn}^{2+}$-doped calcium hydroxyapatite and $\beta$-tricalcium phosphate. J. Inorg. Biochem. 2008, 102, 311-317. [CrossRef] [PubMed]

133. Ananth, P.; Shanmugam, S.; Jose, S.P.; Nathanael, A.J.; Oh, T.H.; Mangalaraj, D.; Ballamurugan, A.M. Structural and chemical analysis of silica-doped $\beta$-TCP ceramic coatings on surgical grade 316L SS for possible biomedical application. J. Asian Ceram. Soc. 2015, 3, 317-324. [CrossRef]

134. Kawabata, A.; Yamamoto, T.; Kitada, A. Substitution mechanism of Zn ions in $\beta$-tricalcium phosphate. Phys. B Condens. Matter 2011, 406, 890-894. [CrossRef]

135. Gokcekaya, O.; Ueda, K.; Ogasawara, K.; Kanetaka, H.; Narushima, T. In vitro evaluation of Ag-incorporated $\beta$-tricalcium phosphate. Mater. Sci. Eng. C 2017, 75, 926-933. [CrossRef] [PubMed]

136. Rau, J.V.; Wu, V.M.; Graziani, V.; Fadeeva, I.V.; Fomin, A.S.; Fosca, M.; Uskoković, V. The bone building blues: Self-hardening copper-doped calcium phosphate cement and its in vitro assessment against mammalian cells and bacteria. Mater. Sci. Eng. C 2017, 79, 270-279. [CrossRef] [PubMed]

137. Zhang, M.; Wu, C.; Li, H.; Yuen, J.; Chang, J.; Xiao, Y. Preparation, characterization and in vitro angiogenic capacity of cobalt substituted $\beta$-tricalcium phosphate ceramics. J. Mater. Chem. 2012, 22, 21686-21694. [CrossRef]

138. Zhu, H.; Guo, D.; Qi, W.; Xu, K. Development of Sr-incorporated biphasic calcium phosphate bone cement. Biomed. Mater. 2017, 12, 015016. [CrossRef] [PubMed]

139. Singh, R.K.; Srivastava, M.; Prasad, N.K.; Kannan, S. Structural analysis and hyperthermia effect of $\mathrm{Fe}^{3+} / \mathrm{Ni}^{2+}$ co-substitutions in $\beta-\mathrm{Ca}_{3}\left(\mathrm{PO}_{4}\right)_{2}$. J. Alloys Compd. 2017, 725, 393-402. [CrossRef]

140. Singh, R.K.; Srivastava, M.; Prasad, N.K.; Awasthi, S.; Dhayalan, A.; Kannan, S. Iron doped $\beta$-tricalcium phosphate: Synthesis, characterization, hyperthermia effect, biocompatibility and mechanical evaluation. Mater. Sci. Eng. C 2017, 78, 715-726. [CrossRef] [PubMed]

141. Gomes, S.; Kaur, A.; Greneche, J.-M.; Nedelec, J.-M. Atomic scale modeling of iron-doped biphasic calcium phosphate bioceramics. Acta Biomater. 2017, 50, 78-88. [CrossRef] [PubMed]

142. Kannan, S.; Goetz-Neunhoeffer, F.; Neubauer, J.; Pina, S.; Torres, P.M.C.; Ferreira, J.M.F. Synthesis and structural characterization of strontium-and magnesium-co-substituted $\beta$-tricalcium phosphate. Acta Biomater. 2010, 6 , 571-576. [CrossRef] [PubMed]

143. Matsumoto, N.; Yoshida, K.; Hashimoto, K.; Toda, Y. Preparation of beta-tricalcium phosphate powder substituted with $\mathrm{Na} / \mathrm{Mg}$ ions by polymerized complex method. J. Am. Ceram. Soc. 2010, 93, 3663-3670. [CrossRef]

144. Meenambal, R.; Kumar, P.N.; Poojar, P.; Geethanath, S.; Kannan, S. Simultaneous substitutions of Gd $\mathrm{G}^{3+}$ and $\mathrm{Dy}^{3+}$ in $\beta-\mathrm{Ca}_{3}\left(\mathrm{PO}_{4}\right)_{2}$ as a potential multifunctional bio-probe. Mater. Des. 2017, 120, 336-344. [CrossRef] 
145. El Khouri, A.; Elaatmani, M.; Ventura, G.D.; Sodo, A.; Rizzi, R.; Rossi, M.; Capitelli, A. Synthesis, structure refinement and vibrational spectroscopy of new rare-earth tricalcium phosphates $\mathrm{Ca}_{9} \mathrm{RE}\left(\mathrm{PO}_{4}\right)_{7}(\mathrm{RE}=\mathrm{La}, \mathrm{Pr}$, Nd, Eu, Gd, Dy, Tm, Yb). Ceram. Int. 2017, 43, 15645-15653. [CrossRef]

146. Goldberg, M.A.; Smirnov, V.V.; Protsenko, P.V.; Antonova, O.S.; Smirnov, S.V.; Fomina, A.A.; Konovalov, A.A.; Leonov, A.V.; Ashmarin, A.A.; Barinov, S.M. Influence of aluminium substitutions on phase composition and morphology of $\beta$-tricalcium phosphate nanopowders. Ceram. Int. 2017, 43, 13881-13884. [CrossRef] 